\title{
The Gulf of Aden: Structure and Evolution of a Young Ocean Basin and Continental Margin
}

\author{
JAMES R. COCHRAN
}

Lamont-Doherty Geological Observatory of Columbia University, Palisades, N. Y. 10964

\begin{abstract}
New marine geophysical data are used to describe the structure and history of the Gulf of Aden. Magnetic anomaly data shows seafioor spreading magnetic anomalies on Sheba Ridge from the axial anomaly to anomaly $5\left(10 \mathrm{~m} . y\right.$. B.P.) between the Owen fracture zone and $45^{\circ} \mathrm{E}$ and to anomaly $2^{\prime}(3 \mathrm{~m} . \mathrm{y}$. B.P.) or anomaly 3 (4 m.y. B.P.) west of $45^{\circ} \mathrm{E}$. The data does not support the two episodes of seafloor spreading recently proposed. Landward of the seafloor spreading magnetic anomalies is a magnetic quiet zone of uncorrelatable anomalies. The magnetic quiet zone boundary is also a structural boundary effectively marking the edge of Sheba Ridge, with deeper basement lacking a significant topographic gradient found on the landward side. A magnetic quiet zone is found not only where Sheba Ridge splits continental lithosphere but also on East Sheba Ridge where the ridge splits the old oceanic lithosphere of the Owen and Somali basins. There the position occupied by the continental margin within the gulf is marked by nonmagnetic ridge complexes that stretch from the continents to the $O$ wen fracture zone. The magnetic quiet zone boundary is not an isochron in either the Gulf of Aden or the Red Sea, suggesting that significant horizontal motions can occur prior to the initiation of seafloor spreading. The offset on the Dead Sea Rift is used to estimate that from 80 to $160 \mathrm{~km}$ of opening, amounting to between $65 \%$ and $200 \%$ extension of the initial rift valley, occurred in the Gulf of Aden and Red Sea prior to the establishment of a mid-ocean ridge. It is suggested that the development of a new ocean basin occurs in two stages. The first involves diffuse extension over an area perhaps $100 \mathrm{~km}$ wide in a rift valley environment without an organized spreading center. This is followed by concentration of the extension at a single axis and the beginning of true seafioor spreading.
\end{abstract}

\section{INTRODUCTION}

The Gulf of Aden can be considered as the type example of a young ocean basin. It has a well-defined continental margin, small oceanic basins, and an active mid-ocean ridge (Sheba Ridge) spreading center characterized by a rift valley and fracture zones. The only other modern continental margin at a similar stage in its development is the Gulf of California, where the situation is complicated by the very large shear component to the rifting and where observation of the basement structures is made difficult by very high sedimentation rates.

The Gulf of Aden would thus appear to be an ideal region for the study of the early evolution of an ocean basin and the processes and structures associated with the rifting and separation of continental lithosphere. However, although its physiography has been described [Laughton, 1966a, b; Laughton et al., 1970], not much is known of the subsurface structure, because very little seismic profiling was done on the extensive British surveys of the mid 1960's [Laughton, 1966a; Matthews et al., 1967; Laughton and Tramontini, 1969; Laughton et al., 1970] that form the published geophysical data base for the Gulf of Aden. In addition, there is disagreement on the age and history of the Gulf of Aden as interpreted from seafloor spreading magnetic anomalies. The two interpretations [Laughton et al., 1970; Girdler and Styles, 1978] disagree by more than a factor of 2 on the age of the magnetic anomalies and suggest completely different histories for the gulf.

This paper uses geophysical data gathered on recent cruises of R. V. Vema along with previously collected data to describe the structure of the Gulf of Aden, to resolve the question of the identification of the magnetic anomalies, and to discuss the history and evolution of this young ocean basin.

The geographic limits of the Gulf of Aden are Cape Guard-

Copyright (C) 1981 by the American Geophysical Union. afui on the northeastern tip of Somalia and Ras Fartak near $52^{\circ} \mathrm{E}$ on the Arabian coast. However, as can be seen on Figure 1, a shallow submarine bank containing several islands extends $400 \mathrm{~km}$ eastward from Cape Guardafui. The easternmost and largest island is Socotra, which consists of Cretaceous and Tertiary shallow water limestones overlying a basement complex of amphibolite grade metamorphic rocks intruded by granites and gabbros [Beydoun and Bichan, 1970] similar to that found in Somalia [Somaliland Oil Exploration Co. Ltd., 1954], and the submarine plateau appears to represent a continuation of the African continent. The effective limits of the Gulf of Aden can thus be marked by a line drawn from the edge of the continental shelf east of Socotra to the 'corner' in the Arabian continental shelf east of Ras Sharbithat and the Kuria Muria Islands. This line runs nearly parallel to the Owen fracture zone, roughly $300 \mathrm{~km}$ northwest of the fracture zone, and cuts the East Sheba Ridge at about the point where the fracture zone offisets change from right lateral to left lateral. However, the entire area west of the Owen fracture zone shares a common history related to the formation and evolution of the Sheba Ridge spreading center and will be considered in this paper.

\section{Previous Geophysical Studies of the Gulf of Aden}

The first study of the Gulf of Aden using an echo sounder was carried out on the John Murray expedition in 1933-1934 and reported by Farquharson [1936]. He recognized a deep 'gully' running eastward out of the Gulf of Tadjura across the shallow, flat western end of the Gulf of Aden to about $45^{\circ} \mathrm{E}$. East of $45^{\circ} \mathrm{E}$, he found that the Gulf deepened and is dominated by a strong northeast-southwest structural grain.

Laughton [1966a] also found that the central portion of the Gulf of Aden east of $45^{\circ} \mathrm{E}$ is dominated by NNE-SSW trending topography and identified this topography as fracture zones [Laughton, 1966b]. He was, however, able to trace the 


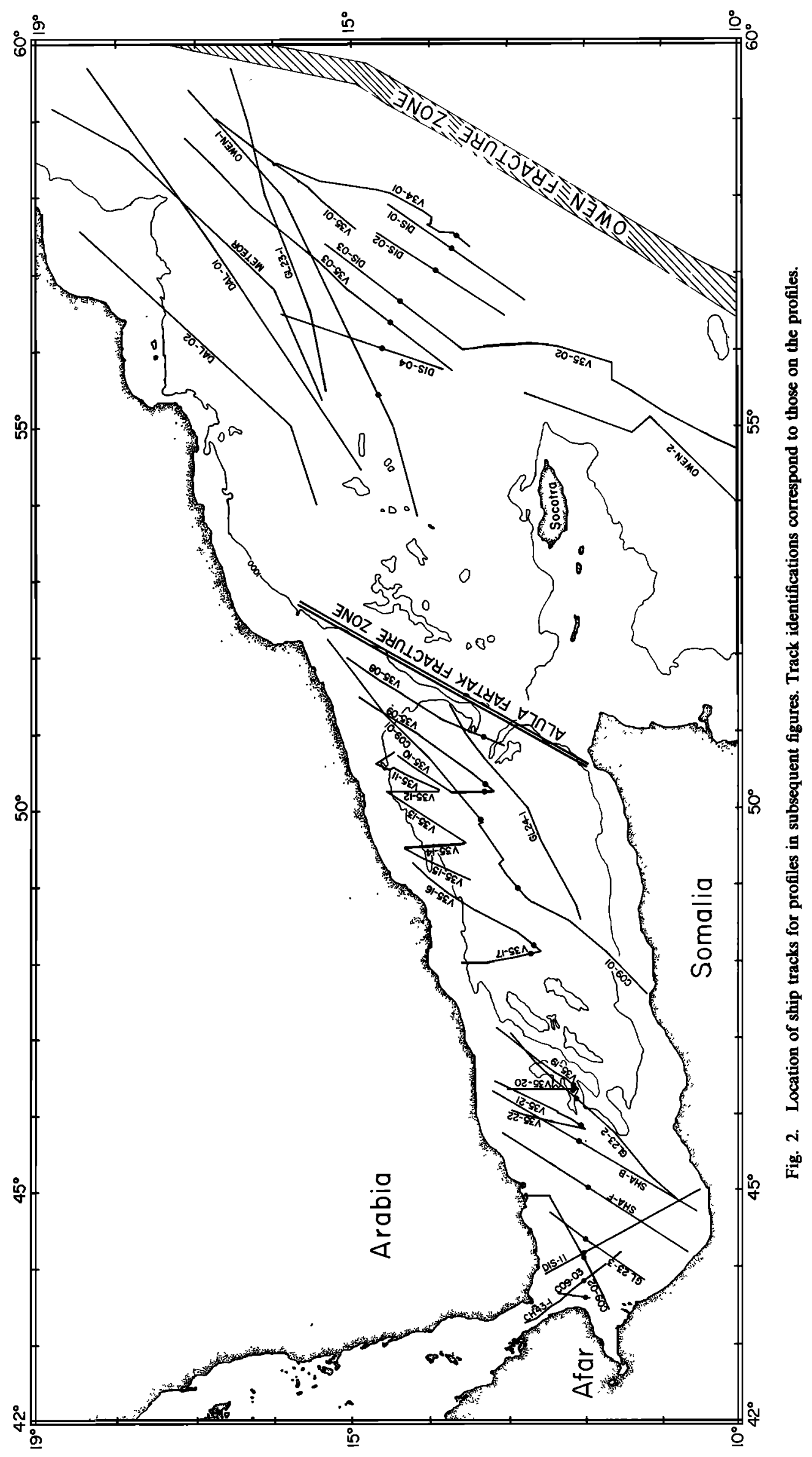




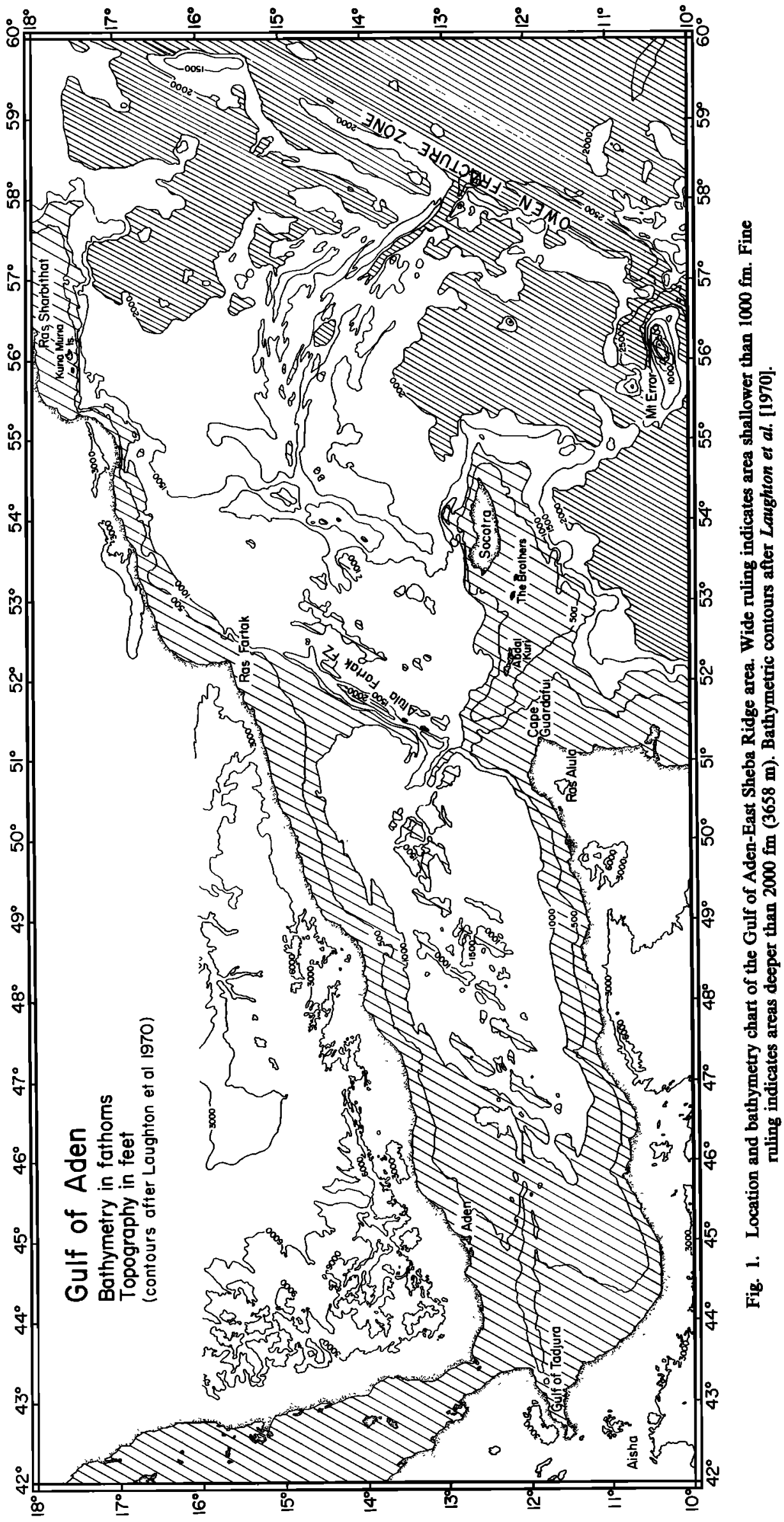




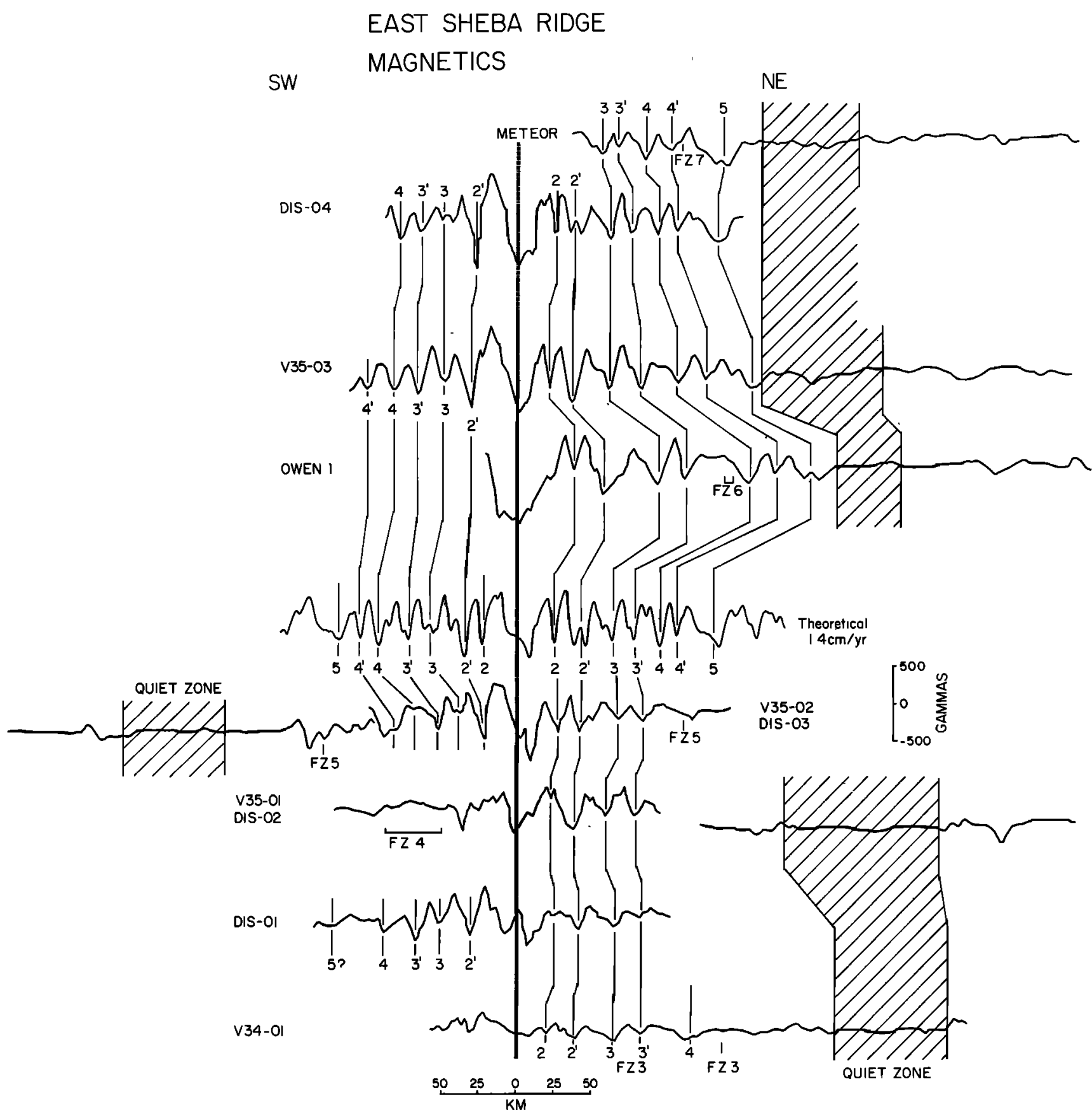

Fig. 3. Total intensity magnetic anomaly profiles from East Sheba Ridge. Location of profiles is shown in Figure 2. All profiles have been projected along $\mathrm{N} 32^{\circ} \mathrm{E}$. Vertical lines show correlations with the theoretical anomalies generated from the geomagnetic reversal sequence of LaBrecque et al. [1977] with inclination $17^{\circ}$ and declination $0^{\circ}$. The limits of the area shaded as the 'quiet zone' were determined from the physiographic boundaries (Figure 12).

rift valley east to the Alula Fartak fracture zone near $52^{\circ} \mathrm{E}$. Matthews et al. [1967] confirmed that the ridge crest continued to the Carlsberg Ridge and gave the name 'Sheba Ridge' to the mid-ocean ridge west of the Owen fracture zone.

Laughton et al. [1970] interpreted magnetic data over the East Sheba Ridge (between the Alula Fartak and Owen fracture zones) and just west of the Alula Fartak fracture zone as a seafloor spreading anomaly sequence out to anomaly 5 (10 m.y. B.P.) generated at a half spreading rate of about $1 \mathrm{~cm} / \mathrm{yr}$. They also assumed on the basis of seismic refraction data [Nafe et al., 1959; Laughton and Tramontini, 1969] that the region between anomaly 5 and the continental margin, a distance of about $75 \mathrm{~km}$, was generated by seafloor spreading. In the western portion of the Gulf of Aden, Laughton et al. [1970] could only correlate magnetic anomalies with assurance out to anomaly 2 ( $2 \mathrm{~m} . \mathrm{y}$. B.P.) to the north of the ridge crest and anomaly 3 (4 m.y. B.P.) to the south.

Laughton et al. [1970] suggested that the initial separation of Arabia and Africa occurred about $20 \mathrm{~m}$.y. B.P. on the basis of early Miocene block faulting in Somalia and Arabia and that an initial period of movement was followed by a hiatus that allowed thick sediments to accumulate in the basins flanking Sheba Ridge prior to the beginning of the present spreading episode at about 10 m.y. B.P.

Recently, Girdler and Styles [1978] interpreted magnetic data obtained on closely spaced tracks in the western Gulf of 


\section{EASTERN GULF OF ADEN MAGNETICS}

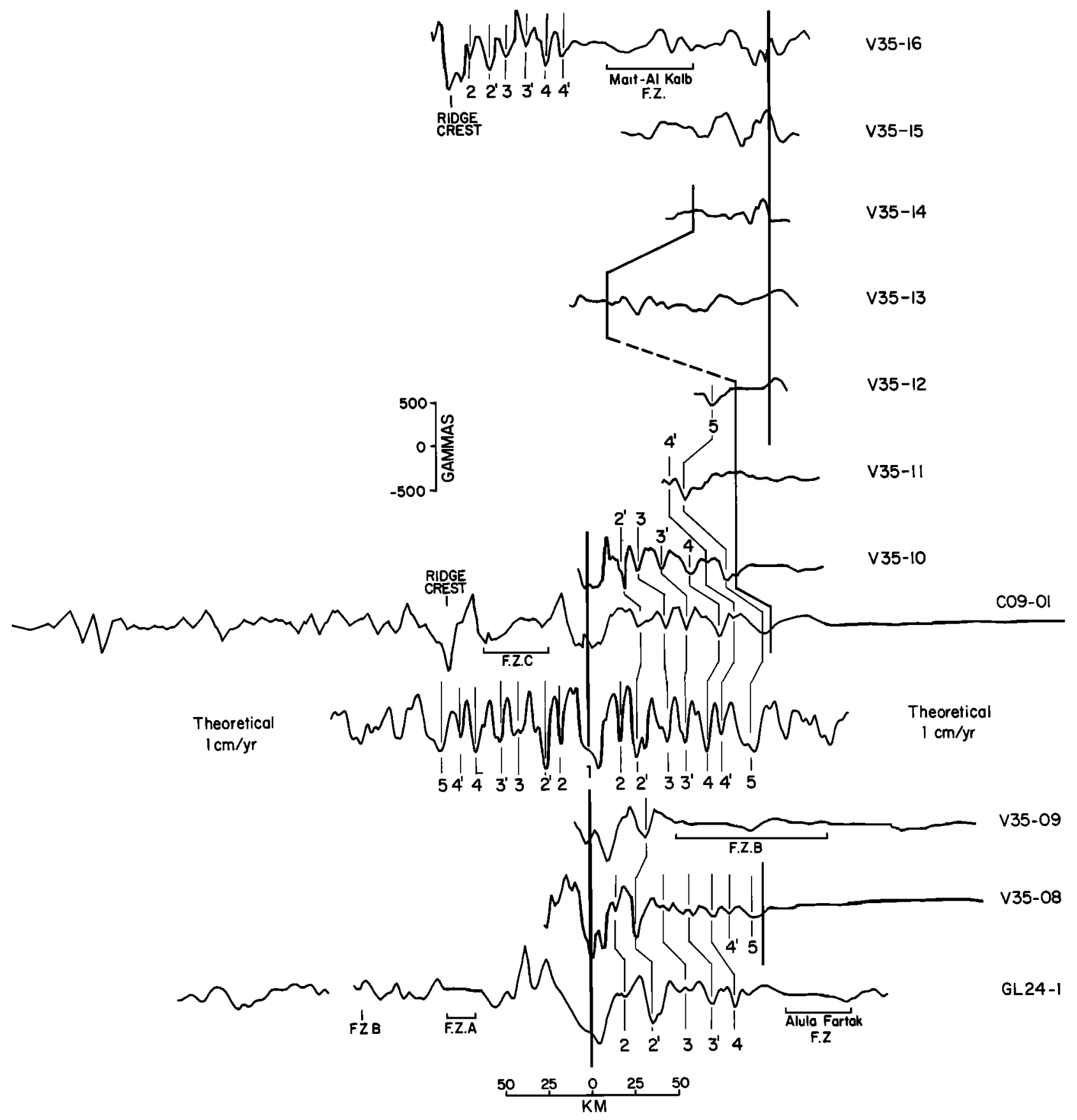

Fig. 4. Total intensity magnetic anomaly profiles from the eastern Gulf of Aden. Location of profiles is shown in Figure 2 . All profiles have been projected along $\mathrm{N} 32^{\circ} \mathrm{E}$. Heavy vertical lines mark the location where acoustic basement deepens suddenly and on profiles V35-12 through V35-16, where it shallows again under the continental rise. Fine vertical lines show correlations with theoretical anomalies generated from the geomagnetic reversal sequence of LaBrecque et al. [1977] with inclination $12^{\circ}$ and declination $0^{\circ}$.

Aden as indicating a much more complicated history. They suggest that the 'Gulf of Aden downwarp' began to form about $40 \mathrm{~m}$.y. B.P. and that seafloor spreading occurred in two distinct phases. The first phase lasted from 30 m.y. B.P. to about 15 m.y. B.P. and was followed by a 10-m.y. hiatus. The second stage of spreading began about $5 \mathrm{~m} . \mathrm{y}$. B.P. and has continued to the present.

\section{Magnetic Anomalies Over Sheba Ridge}

The available magnetic anomaly data across Sheba Ridge are shown in Figures 3-6 as projected profiles of total intensity magnetic anomalies formed by projecting the data along an aximuth of $32^{\circ}$, approximately parallel to the fracture zone trend. Location of the ship tracks is shown in Figure 2. 


\section{CENTRAL GULF OF ADEN}

\section{MAGNETICS}

A.

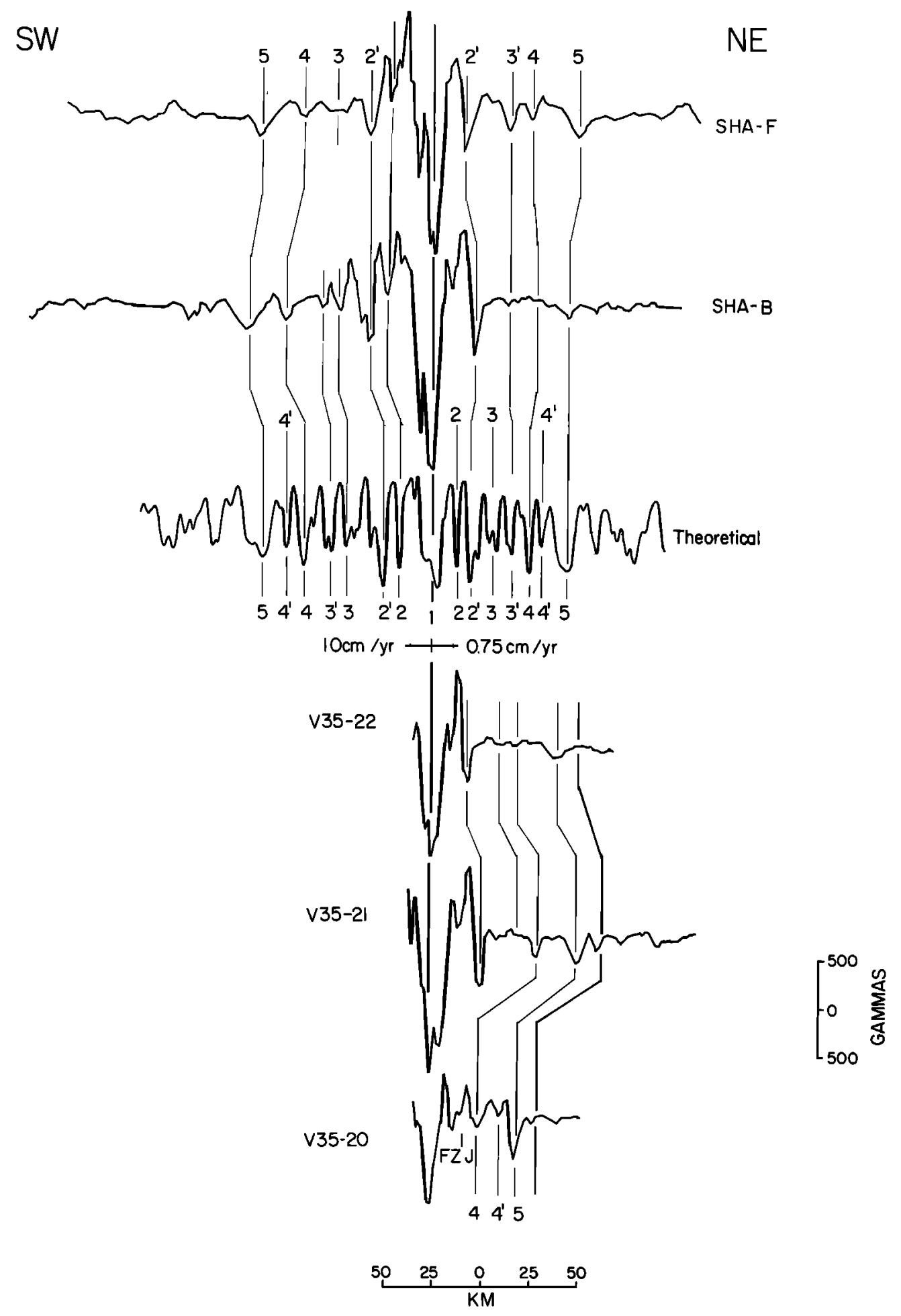

Fig. 5a. Totai intensity magnetic anomaly profiles from the central Gulf of Aden. Location of profiles is shown in Figure 2. All profiles have been projected along N32 ${ }^{\circ} \mathrm{E}$. Heavy vertical line (profiles V35-20, V35-21, and V35-22) marks the location where acoustic basement deepens suddenly. Fine vertical lines show correlations with theoretical anomalies generated from the geomagnetic reversal sequence of LaBrecque et al. [1977] with inclination $7^{\circ}$ and declination $0^{\circ}$. 
B.

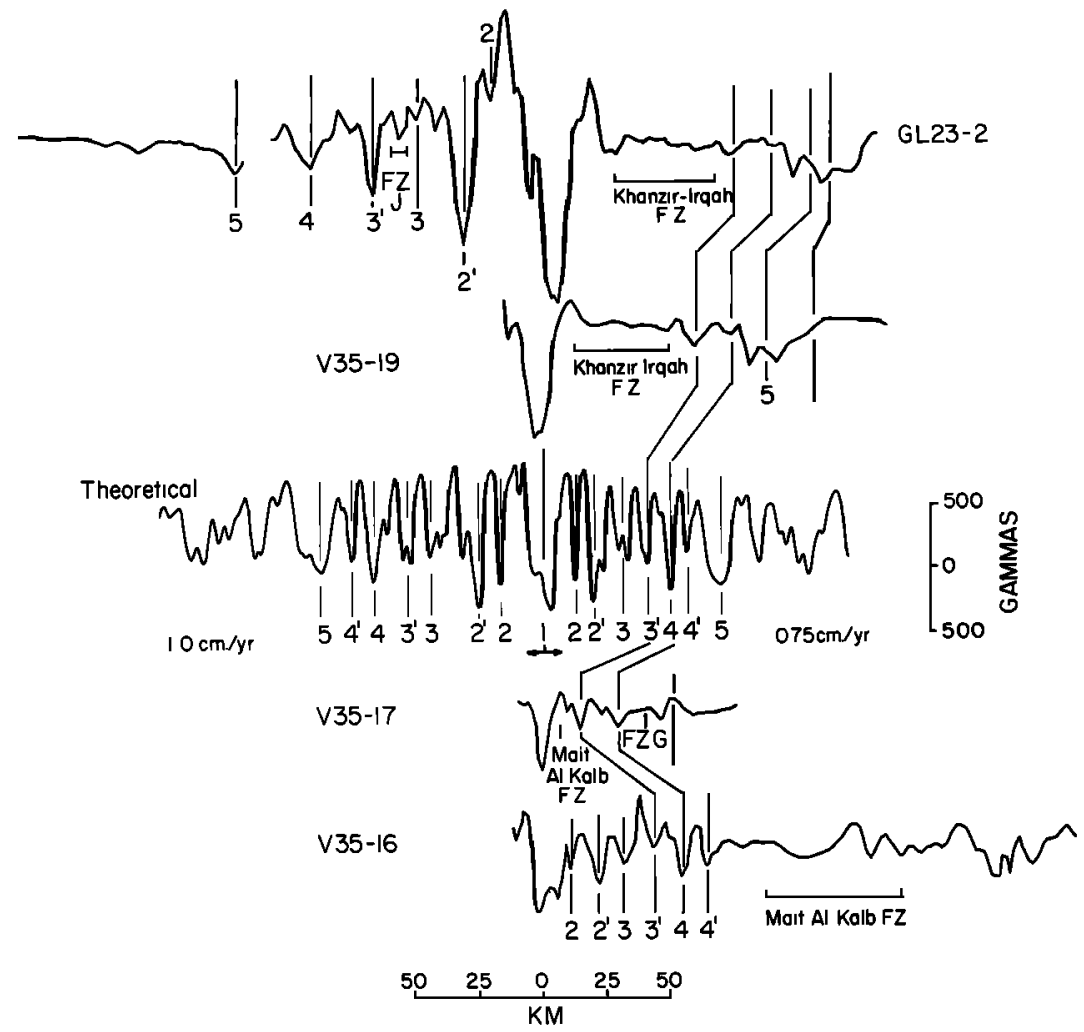

Fig. 5b. Total intensity magnetic anomaly profiles from the central Gulf of Aden. Location of profiles is shown in Figure 2 . All profiles have been projected along $\mathrm{N} 32^{\circ} \mathrm{E}$. Heavy vertical lines mark the location where acoustic basement deepens suddenly. Fine vertical lines show correlations with theoretical anomalies generated from the geomagnetic reversal sequence of LaBrecque et al. [1977] with inclination $7^{\circ}$ and declination $0^{\circ}$.

Magnetic anomaly profiles across the East Sheba Ridge (Figure 3) are primarily from the eastern part of the ridge, east of about $55^{\circ} \mathrm{E}$. The observed magnetic anomalies have been correlated with a theoretical profile generated by using the geomagnetic reversal time scale of LaBrecque et al. [1977] with a half spreading rate of $1.4 \mathrm{~cm} / \mathrm{yr}$. They appear to form a continuous sequence from anomaly 1 through anomaly 5 . In particular, note the very good agreement in the character of the anomalies between profile V35-03 and the theoretical profile, including many of the small details. This interpretation basically agrees with that of Laughton et al. [1970], although their anomaly correlations on the north side of the ridge crest in profiles DIS-01, DIS-02, and DIS-03 (their profiles LK, $M N$, and $O R$ ) have been slightly modified. Beyond anomaly 5 , the amplitude of the magnetic anomalies drops sharply, forming a magnetic 'quiet zone.'

Magnetic anomaly profiles from the eastern part of the Gulf of Aden between about $48^{\circ} \mathrm{E}$ and $51^{\circ} \mathrm{E}$ (Figure 4) are almost entirely from the northern half of the Gulf of Aden. The magnetic anomalies can again be easily correlated with the geomagnetic reversal sequence as anomalies 1 through 5. Note particularly the good agreement between the theoretical profile and profiles C09-01 and V35-10.

Anomaly 5 marks the end of the correlatable magnetic sequence, and a 'magnetic quiet zone' is found between anomaly 5 and the Arabian continental margin. In the eastern profiles (profiles V35-08 to V35-12) the magnetic quiet zone is, in fact, very smooth. West of fracture zone C (Figure 8) there are magnetic anomalies with amplitudes of up to about $450 \gamma$ be- tween anomaly 5 and the coast, but they are not correlatable between tracks.

Magnetic anomaly profiles from the central and western Gulf of Aden (Figures 5 and 6) are not as simple to interpret as those to the east. The amplitude of the axial anomaly increases from about $1000 \gamma$ to more than $2000 \gamma$ near $46^{\circ} \mathrm{E}$ (compare profiles V35-16 and V35-17 near $48^{\circ} \mathrm{E}$ with profile GL23-2 near $46^{\circ} \mathrm{E}$ ). Also, the amplitude of the older anomalies is greatly reduced on most profiles, making identification of the anomalies difficult. However, on a few profiles the magnetic anomaly sequence can be clearly identified as anomalies 1 through 5 (see particularly profiles SHA-B and SHA-F), and the tracks are closely spaced enough that they can be correlated with some confidence from track to track, as shown in Figure 5.

West of fracture zone $M$ (near $44.5^{\circ} \mathrm{W}$ ), the magnetic anomalies can only be correlated with the geomagnetic time scale from the ridge axis out to anomaly $2^{\prime}$ (about 3 m.y. B.P.) or perhaps anomaly 3 (4 m.y. B.P.) (see Figure 6).

An alternative interpretation of the magnetic anomalies in the central Gulf of Aden has been given by Girdler and Styles [1978], who used 16 profiles west of $46^{\circ} \mathrm{E}$ to develop a twostage seafloor spreading history for the Gulf of Aden. They did this by assuming that the beginning of the present phase of seafloor spreading coincided with the end of salt deposition in the Red Sea at the Miocene-Pliocene boundary ( 5 m.y. B.P.) and that older anomalies could have formed at any time between $40 \mathrm{~m} . y$. B.P. and $5 \mathrm{~m} . \mathrm{y}$. B.P. They chose the period between $30 \mathrm{~m}$.y. B.P. and either 17 or $15 \mathrm{~m}$.y. B.P. as giving 


\section{WESTERN GULF OF ADEN \\ MAGNETICS}

SW

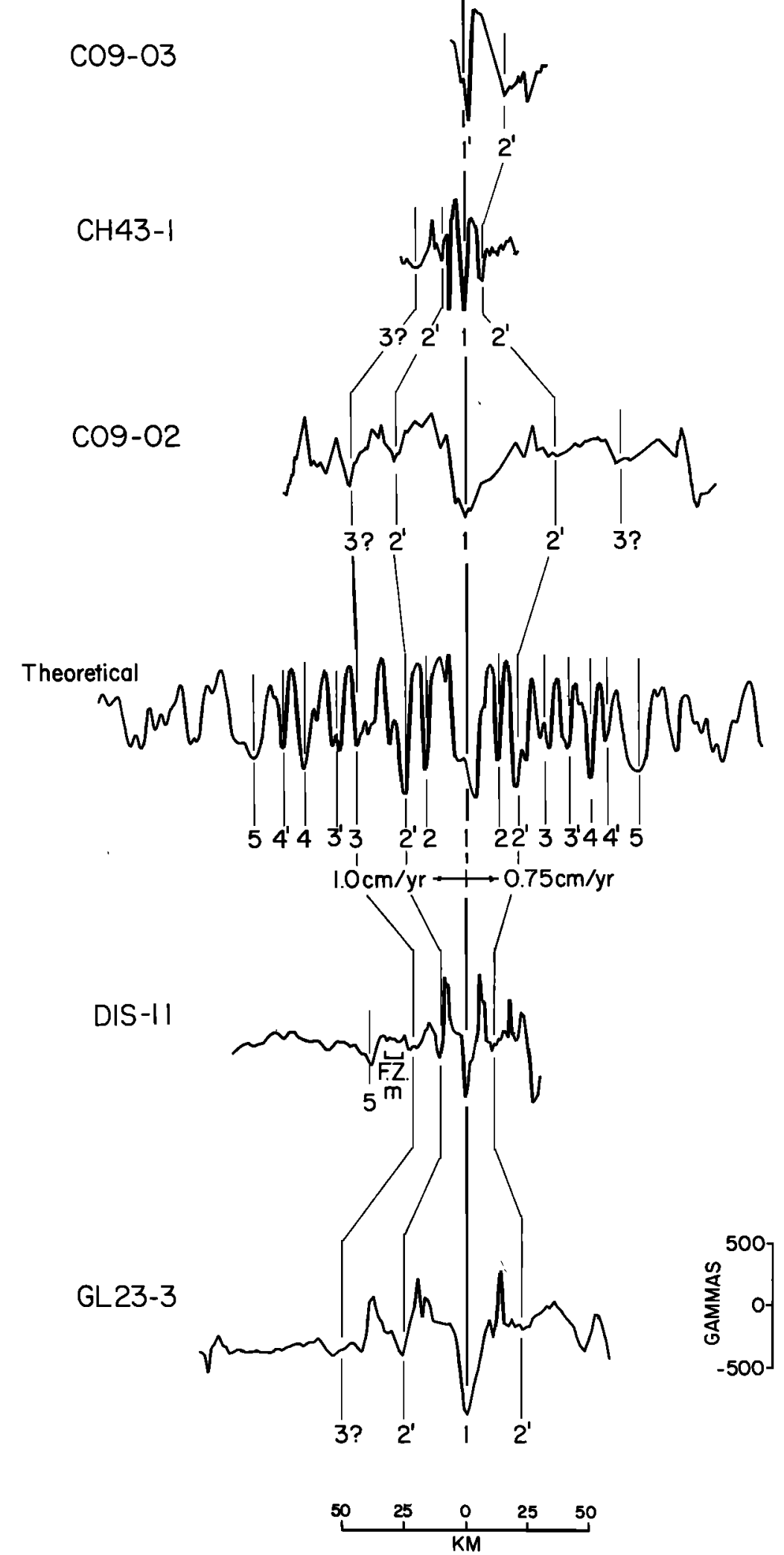

Fig. 6. Total intensity magnetic anomaly profiles from the western Gulf of Aden. Location of profiles is shown in Figure 2 . All profiles have been projected along N32 ${ }^{\circ} \mathrm{E}$. Fine vertical lines show correlations with theoretical anomalies generated from the geomagnetic reversal sequence of LaBrecque et al. [1977] with inclination $7^{\circ}$ and declination $0^{\circ}$. 


\section{MAGNETIC ANOMALIES}

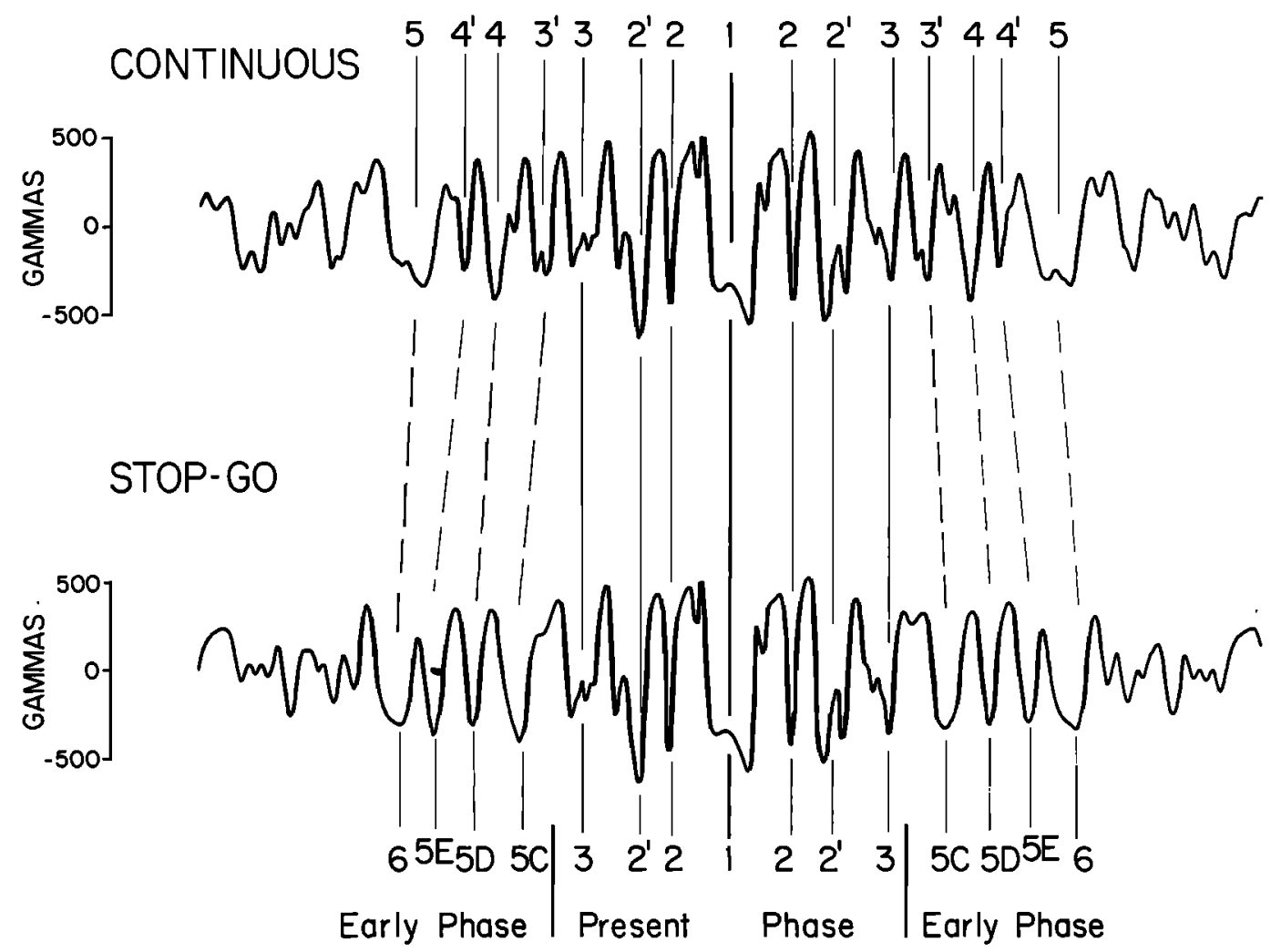

\section{REVERSAL SEQUENCE}

CONTINUOUS
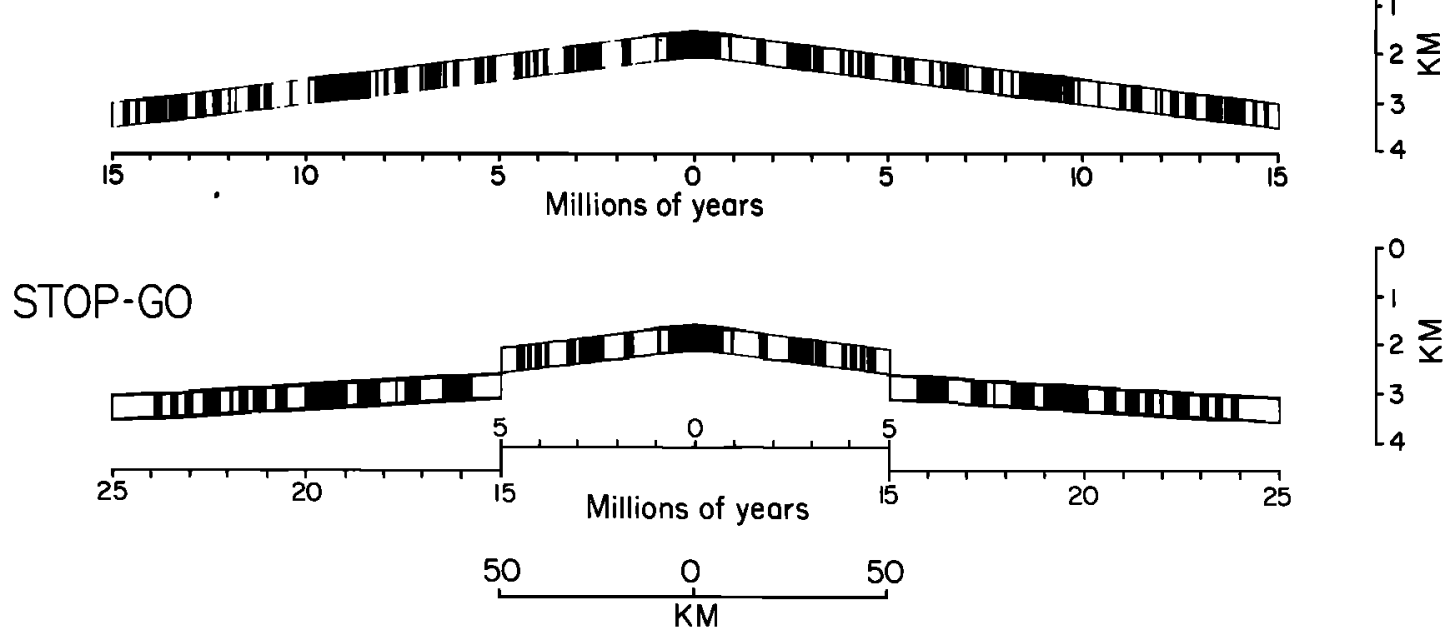

Fig. 7. Comparison of magnetic anomalies from continuous seafloor spreading over the past $15 \mathrm{~m} . \mathrm{y}$. and those generated by the 'stop-go' model of Girdler and Styles [1978] where there is a hiatus from $15 \mathrm{~m}$.y. B.P. to $5 \mathrm{~m}$.y. B.P. Note the similarity in the general character of the anomalies generated by the two models. The geomagnetic reversal sequence of LaBrecque et al. [1977] was used with inclination $7^{\circ}$ and declination $0^{\circ}$, parameters appropriate for the central and western portion of the Gulf of Aden. The magnetized body was considered to be $500 \mathrm{~m}$ thick with a magnetization of $0.012 \mathrm{emu} /$ $\mathrm{cm}^{3}$ and to slope away from the ridge crest at $100 \mathrm{~m} / \mathrm{m}$.y. A similar model was used for the synthetic anomalies in Figures 3-6 with ridge crest depths of $2500 \mathrm{~m}$ (Figure 3), $2000 \mathrm{~m}$ (Figure 4), and $1500 \mathrm{~m}$ (Figures 5 and 6). A slope of $45 \mathrm{~m} / \mathrm{m}$.y. is used for the early phase of the 'stop-go' model. 
TABLE 1. Spreading Rates Determined From Magnetic Anomalies

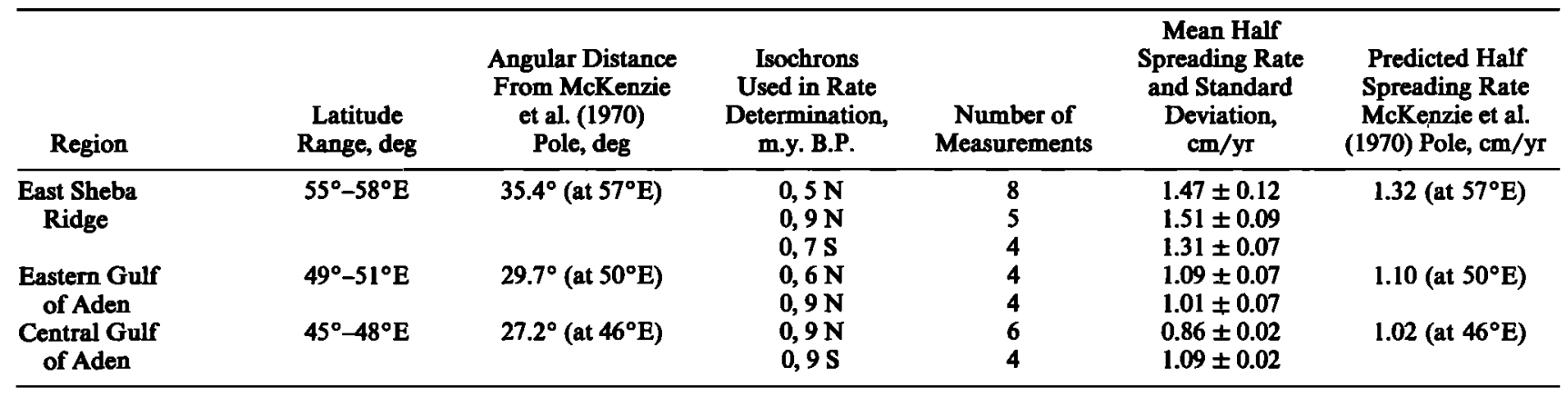

the best match to the observed anomalies, and in the two profiles that they show (profiles SHA-B and SHA-F, figure 5) they do obtain a very good fit.

Actually, the sections of the geomagnetic time scale chosen by Girdler and Styles [1978] give a sequence of magnetic anomalies remarkably similar in general appearance to those generated by continuous spreading, with anomalies $5 \mathrm{C}$, 5D, $5 E$, and 6 occupying the positions of anomalies $3^{\prime}, 4,4^{\prime}$, and 5 , respectively (see Figure 7). The very good fit obtained by Girdler and Styles [1978] thus depends not so much on the section of the time scale that they used as it does on special assumptions that they made in their modeling. Specifically, they assumed that:

1. The magnetization resides in layer 2 for the present stage of spreading, but it resides in layer 3 for the older phase, because there is too much high frequency signal on the synthetic profile when the depth constraints of the seismic refraction lines are used' [Girdler and Styles, 1978, p. 615].

2. Layer 3 (the magnetized body) is $4 \mathrm{~km}$ thick on the southern limb of profile $F$ and $6 \mathrm{~km}$ thick on the northern limb. On profile B, both limbs have a 4-km-thick layer 3. This assumption gives the larger-amplitude anomalies observed on the northern limb of profile F (see Figure 5, profile SHA-F).

3. In profile $F$, the first stage of spreading ended at $17 \mathrm{~m} . y$. B.P., while in Profile B it ended between 14 and 15 m.y. B.P. This 2-m.y. difference results in an additional anomaly (anomaly $5 \mathrm{C}$ ) being present on profile $\mathrm{B}$.

4. In profile $F$, the axis of the second phase of spreading coincides with that of the first, while in profile $B$, it is offset to the north. This assumption results in both anomaly 5C's being on the southern limb of profile $B$. This was done in response to an apparent asymmetry in that profile.

5. The spreading during the early stage was asymmetric by $13 \%$ in profile $F$, while it is symmetric in profile $B$.

These assumptions, although resulting in a good fit to the observed profiles, involve both an unusual and very complicated history for Sheba Ridge and a great number of differences in the history recorded in two profiles that are only about $40 \mathrm{~km}$ apart.

The continuous spreading history proposed by Laughton et al. [1970] and by this paper results in a much simpler history for the Sheba Ridge, which gives an acceptable fit to the observed magnetic anomalies in the western and central Gulf of Aden and a very good fit, including many of the minor details, in the eastern Gulf of Aden and on East Sheba Ridge, where the anomaly pattern is much better developed.

In addition, there is no evidence of the depth discontinuity that would be expected from a $10-\mathrm{m} . y$. spreading hiatus. The difference between the average ridge crest and the $10-\mathrm{m} . y$. isochron depths, corrected for sediment loading, is $875 \mathrm{~m}$ for East Sheba Ridge, $950 \mathrm{~m}$ for the region between the Alula Fartak and Mait Al Kalb fracture zones, and $1040 \mathrm{~m}$ west of the Mait Al Kalb fracture zone. These values are well within the range of mean values below the ridge crest documented for anomaly 5 by Sclater et al. [1971] and very close to their average of between 900 and $950 \mathrm{~m}$. If anomaly 5 were actually anomaly 6, as is proposed by Girdler and Styles [1978], then about $1400 \mathrm{~m}$ of subsidence would be expected.

The magnetic anomaly identifications are shown as a magnetic lineation chart in Figure 8. The location and trend of the fracture zones shown in Figure 8 were determined from bathymetric and gravity data from numerous east-west ship tracks, as well as from offsets in the magnetic lineations and the ridge crest. In placing fracture zones, it was assumed that they are marked by topographic troughs and the associated gravity minima. The fracture zone trends generally agree quite well with small circles about the McKenzie et al. [1970] Arabia-Somalia pole at $26.5^{\circ} \mathrm{N}, 21.5^{\circ} \mathrm{E}$. Names have been given to several of the prominent fracture zones by combining the names of geographic features on shore at either end of them, the same method that was used in naming the Alula Fartak fracture zone.

The average spreading rates, as determined by measuring the distance to isochrons along the fracture zone trend, are shown in Table 1 . The average measured total spreading rates are $2.82 \mathrm{~cm} / \mathrm{yr}$ for the eastern end of the East Sheba Ridge (Figure 3), $2.1 \mathrm{~cm} / \mathrm{yr}$ for the eastern Gulf of Aden (Figure 4), and $1.95 \mathrm{~cm} / \mathrm{yr}$ for the central Gulf of Aden (Figure 5). Much of the variation in spreading rates is simply due to variation in distance from the pole, as can be seen in Table 1 .

The spreading in the central Gulf of Aden $\left(45^{\circ} \mathrm{E}-48^{\circ} \mathrm{E}\right)$ appears to be asymmetric. The average spreading rate between the ridge axis and the 9-m.y. isochron is $0.86 \pm 0.02 \mathrm{~cm} / \mathrm{yr}$ on the north side and $1.09 \pm 0.02 \mathrm{~cm} / \mathrm{yr}$ on the south side. The data from East Sheba Ridge also appear to imply asymmetric spreading, with an average spreading rate of $1.51 \mathrm{~cm} / \mathrm{yr}$ on the north side and $1.31 \mathrm{~cm} / \mathrm{yr}$ on the south side. However, given the large standard deviations of the determinations, which are probably due in part to navigational uncertainties, the significance of this observation is not certain.

\section{Magnetic Quiet Zone}

The boundary between the seafloor spreading magnetic anomalies over the Sheba Ridge and the magnetic 'quiet zone' bordering them coincides with a major structural boundary. At this location, there is a noticeable increase in the depth to basement on every line for which seismic profiling data is 


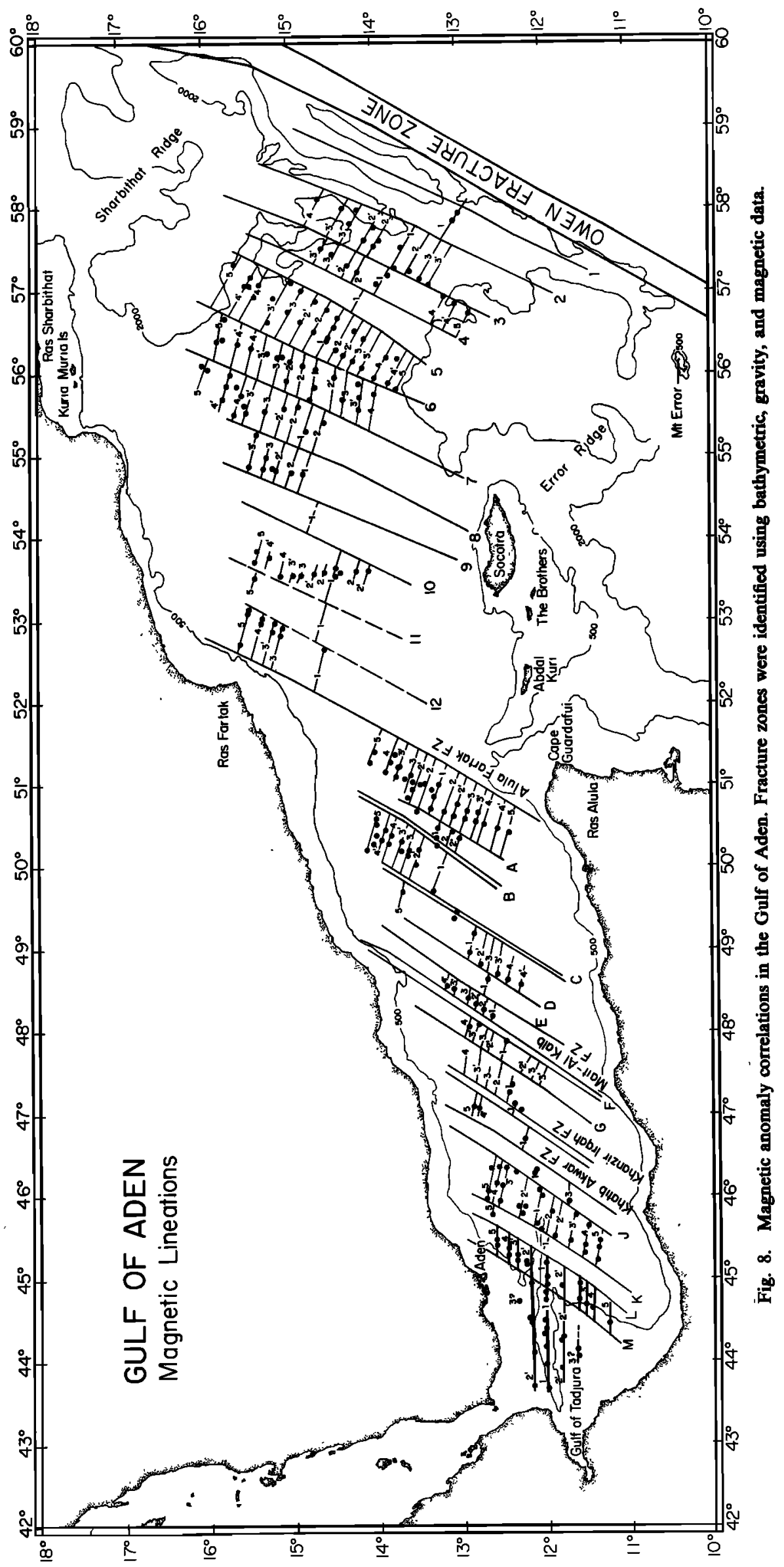




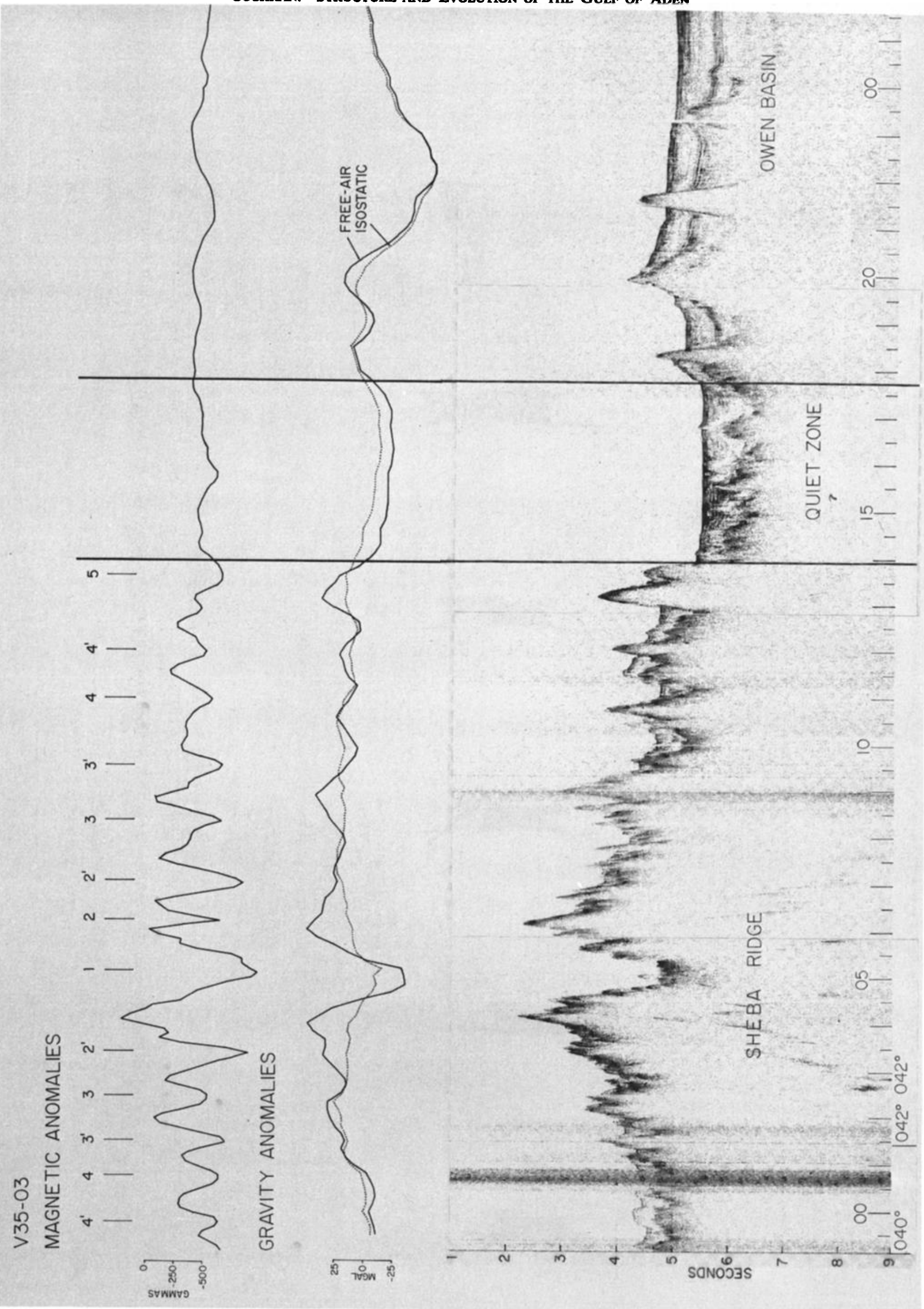


available (see Figures 9-11). In some profiles (Figures 10 and 11), the boundary is marked by the disappearance of basement on the seismic records. On other profiles (Figure 9) where the basement is still visible, it is from $300 \mathrm{~m}$ to more than $1 \mathrm{~km}$ deeper. A gravity low is found over the magnetic quiet zone throughout much of the Gulf of Aden (Figures 911), although the gradient marking the seaward edge of the gravity low does not always coincide with the quiet zone boundary.

On some profiles (for example, Figure 11) the acoustic basement rises sharply beneath the upper continental slope and shelf. The continental shelf and coastal plain are generally narrow and are bounded by escarpments marking the edge of the 1- to 2-km-high plateaux bordering the Gulf of Aden. The basement scarps seen near the edge of the shelf appear to be a continuation of the plateau edge escarpments, which were formed by large-scale normal faulting in the Late Oligocene or earliest Miocene and mark the boundary of the Gulf of Aden rift.

Where the basement in the quiet zone is visible, it is at a nearly uniform depth and does not appear to deepen away from the ridge crest. The combination of the discontinuity in depth and the lack of a basement depth gradient across the quiet zone implies that the quiet zone boundary marks the limit of crust generated at an organized Sheba Ridge spreading center and that the crust between the edge of the quiet zone and the large normal faults at the continental margin has some other origin.

On the East Sheba Ridge, the position occupied by the continental margin within the Gulf is marked by a series of nonmagnetic ridges (Figures 9, 12, and 13). One ridge complex, which we call Sharbithat ridge, extends along the boundary of the northern quiet zone from the continental shelf off Ras Sharbithat at $18^{\circ} \mathrm{N}$ in Oman to the Owen fracture zone near $15^{\circ} 30^{\prime} \mathrm{N}$ where there is a change in the trend of the fracture zone. The second ridge complex, which we call Error ridge, runs from the eastern edge of the continental shelf east of Socotra to the Owen fracture zone near $10^{\circ} \mathrm{N}$ and includes $\mathrm{Mt}$. Error [Matthews, 1966]. The intersection of Error ridge and the Owen fracture zone also coincides with a change in trend of the fracture zone (see Figure 6). The two ridge complexes appear as a series of seamounts on Laughton et al.'s [1970] bathymetry map, but every track through the area crosses a seamount (Figure 12), and there is a several hundred meter difference in depth across Sharbithat ridge, suggesting that it forms a nearly continuous barrier to sediment transported from the north.

Along the outer edge of each ridge complex, there is a band of very negative gravity anomalies with values more than 50 mgal less than the regional field in the basins beyond (Figure 13).

There is not much information available concerning the Owen and Somali basins, which flank the Sheba Ridge. The oceanic nature of both basins is documented by seismic refraction results [Francis et al., 1966; Whitmarsh, 1979]. Geometric considerations and paleomagnetic data suggest that they were created by the southeastern movement of Greater

Fig. 9. (Opposite) Seismic reflection, free air, and isostatic gravity anomaly and total intensity magnetic anomaly profiles along line V35-03 on the East Sheba Ridge. Numbers over the magnetic anomalies are correlations with the geomagnetic reversal sequence (Figure 3). One hour of time on the seismic reflection record is equivalent to $15-18 \mathrm{~km}$ of distance. Location is shown in Figure 2.
India and Madagascar relative to Africa/Arabia, probably starting in Jurassic times [Embleton and Valencio, 1977]. The discovery of magnetic anomalies MO through M22 in the Mozambique Basin [Simpson et al., 1979] would tend to support this interpretation. Lineated magnetic anomaly sequences have not been identified in either the Somali Basin or the Owen Basin, although Whitmarsh [1979] suggests the presence of WSW-ENE lineated magnetic anomalies in the Owen Basin.

\section{Western Gulf of Aden}

There is a marked change in the nature of Sheba Ridge across fracture zone $\mathrm{M}$ between $44^{\circ}$ and $45^{\circ} \mathrm{E}$. East of that fracture zone, the ridge has the characteristic morphologic form of a slow-spreading mid-ocean ridge, and although the crestal depth decreases steadily from about $2500 \mathrm{~m}$ near the Owen fracture zone to $800 \mathrm{~m}$ at $45^{\circ} \mathrm{E}$, the subsidence away from the ridge remains close to the worldwide average. West of fracture zone $M$, the spreading axis takes the form of a trough or rift similar to the axial trough found in the Red Sea. This does not appear to be simply due to burial of the ridge flanks under sediment, since there is no sign of a buried midocean ridge morphology or of subsidence away from the rift. (See seismic reflection profile GL23-3, Figure 14). The Sheba Ridge maintains a rift valley form across the westerp end of the Gulf of Aden, through the Gulf of Tadjura, and, as the Ardoukoba Rift,' a subaerially exposed rift valley [Harrison et al., 1975; Needham et al., 1976], into Afar.

Fracture zone $M$ also marks the western limit to which the magnetic anomaly sequence to anomaly 5 can be identified. West of the fracture zone, magnetic anomalies can only be identified from the axial anomaly to anomaly 2' (about $3 \mathrm{~m}$.y. B.P.) or anomaly 3 (4 m.y. B.P.). Also, there is little or no offset in the ridge axis across fracture zone $M$ (see Figure 8), even though it corresponds to the approximately $100-\mathrm{km}$ offset in the Arabian margin at $45^{\circ} \mathrm{E}$, resulting in the ridge axis being displaced well to the northern side of the gulf (Figures 8 and 14). It thus appears that the present Sheba Ridge spreading center formed west of fracture zone $M$ at 3-4 m.y. B.P., and it did so not in the center of the Gulf but near the Arabian margin as a continuation of the already existing ridge to the east.

These two observations, the change in the morphologic character of the ridge and the lack of seafloor spreading magnetic anomalies older than $4 \mathrm{~m} . y$. , suggest that a organized mid-ocean ridge did not begin to form west of fracture zone $M$ until about $4 \mathrm{~m} . y$. B.P. Even if there was no mid-ocean ridge to the west of fracture zone $M$ prior to $4 \mathrm{~m}$.y. B.P., extension in some form must have been occurring since at least 10 m.y. B.P., because seafloor spreading magnetic anomalies of that age are found to the east, and no transform fault exists across Arabia or Somalia to absorb the motion. The fact that the need for extension within the quiet zone can be demonstrated for this area in the western Gulf of Aden suggests that the development of the quiet zone in the rest of the Gulf of Aden might also involve extension. The extension could have occurred at a localized spreading center which, for some reason, did not result in the formation of a mid-ocean ridge topographic gradient and magnetic anomalies or might have been spread in a diffuse manner across the Gulf of Aden rift.

\section{Afar}

Although it may not be valid to generalize from an obviously unusual area such as Afar, which overlies a mantle hot 


\section{MAGNETIC ANOMALIES}

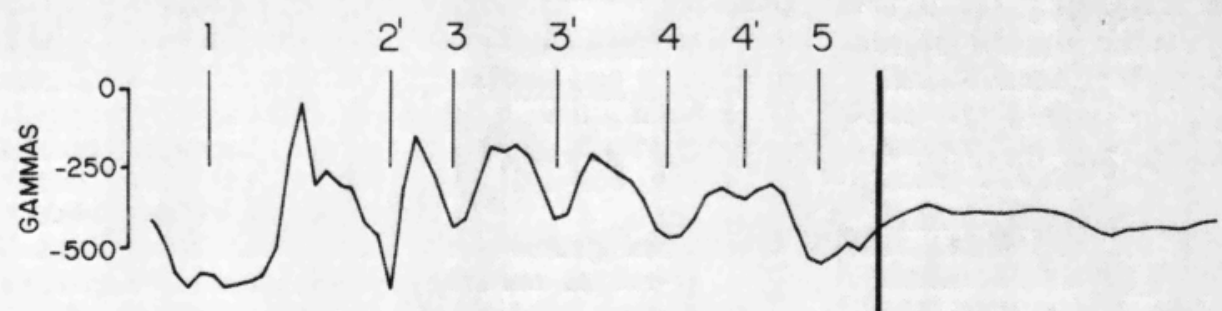

\section{GRAVITY ANOMALIES}
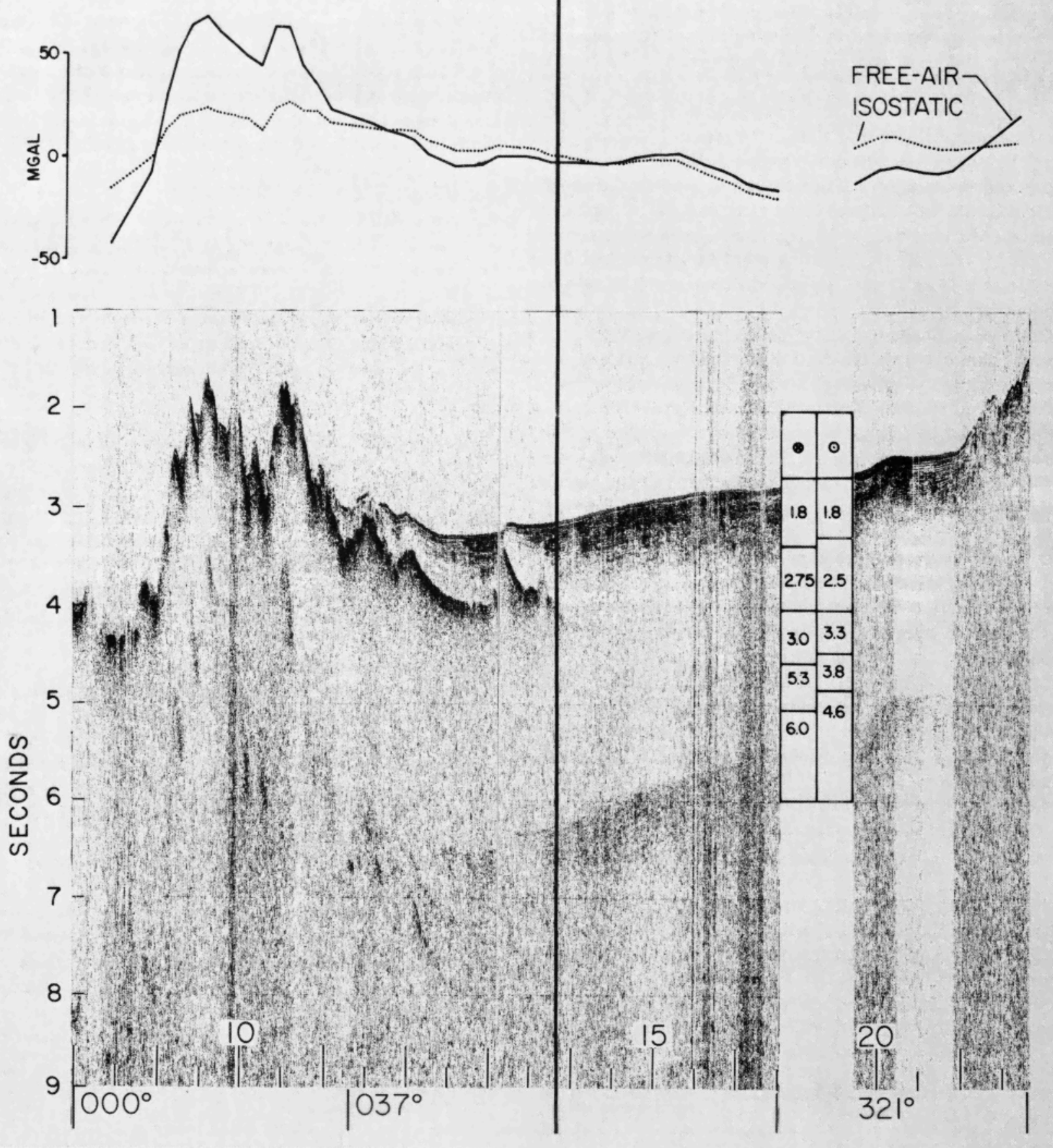

Fig. 10. Seismic reflection, free air, and isostatic gravity anomaly and total intensity magnetic anomaly profiles along line V35-10 in the eastern Gulf of Aden. Numbers over the magnetic anomalies are correlations with the geomagnetic reversal sequence (Figure 4). The two seismic sections are from expendable sonobuoy refraction lines run perpendicular to the profile. One hour of time on the seismic reflection record is equivalent to 15-18 $\mathrm{km}$ of distance. Location is shown in Figure 2. 
V35-21

MAGNETIC ANOMALY
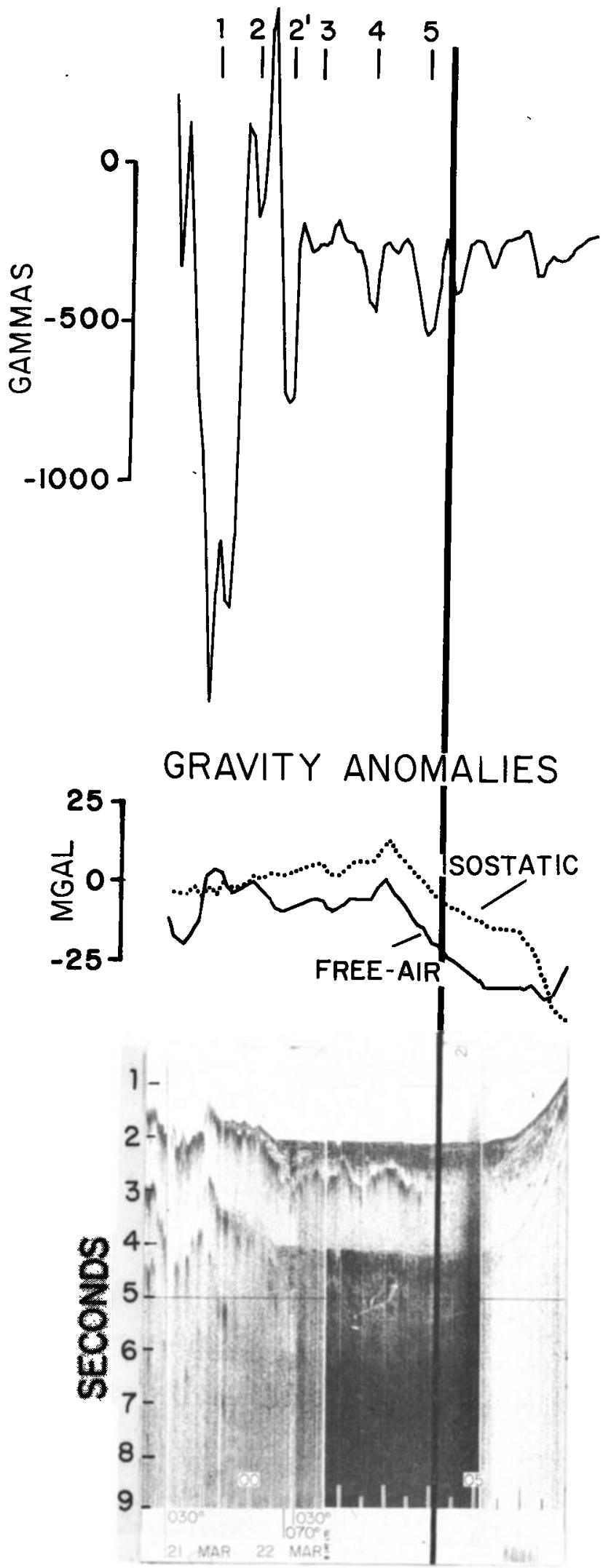

Fig. 11. Seismic reflection, free air, and isostatic gravity anomaly and total intensity magnetic anomaly profiles along line V35-21 in the central Gulf of Aden. Numbers over the magnetic anomalies are correlations with the geomagnetic reversal sequence (Figure 5). One hour of time on the seismic reflection record is equivalent to $15-18 \mathrm{~km}$. Location is shown in Figure 2. spot [Schilling, 1973], the early stages in the rifting process and initiation of a localized spreading center can be observed there.

As mentioned in a previous section, Sheba Ridge extends into eastern Afar as the Ardoukoba Rift, a subaerially exposed rift valley that extends about $15 \mathrm{~km}$ northwest from Ghoubat-al-Kharab, an embayment at the southwestern end of the Gulf of Tadjura, to Lake Asal. It is about $10 \mathrm{~km}$ wide and from $400 \mathrm{~m}$ to $1 \mathrm{~km}$ deep, and it is characterized by recent basalts and open fissures [Harrison et al., 1975; Needham et al., 1976]. The Ardoukoba Rift is one of a series of 'axial volcanic ranges,' either rift valleys or lines of central volcanoes, which have formed in Afar during the past million years [Barberi, $1972 a, b$; Civetta et al., 1975] and which are arranged en echelon across Afar from the Gulf of Tadjura to the Gulf of Zula on the Red Sea in northwest Afar. Away from the axial ranges the floor of much of the Afar Depression is covered with basalts of the Afar Stratoid series, which were erupted since 4 m.y. B.P. and are severely affected by extensional tectonics [Barberi et al., 1975; Christiansen et al., 1975]. Both the extensional faulting and volcanic activity of the Afar Stratoid series occurred throughout the Afar depression and have only recently (within the past million years) become localized at organized centers. This has been explained by Courtillot et al. [1980] in terms of the westward propagation of the Sheba Ridge from the Gulf of Aden into Afar.

The prerift rocks exposed within Afar at the Danakil and Aisha 'horsts' are not part of rigid blocks but are intensely faulted on normal faults, resulting in a series of tilted blocks that have been rotated as much as $45^{\circ}$ [Black et al., 1972; Morton and Black, 1975]. It is suggested that they are representative of the rocks under the volcanics of the Afar depression and stand higher, simply because they are on the less severely affected margins of the zone of extension.

\section{The Red Sea}

The opening of the Gulf of Aden and the Red Sea are intimately related, since both result from the motion of Arabia away from Africa; and except for the degree of freedom provided by the East African Rift, one defines the other. Thus the Red Sea can provide constraints on the evolution of the Gulf of Aden.

The morphology of the Red Sea consists of broad continental shelves, a wide 'main trough' that extends from about $14^{\circ} \mathrm{N}$ to the tip of the Sinai Peninsula $\left(28^{\circ} \mathrm{N}\right)$ at a depth of about $1000 \mathrm{~m}$, and a narrow 'axial trough' found from about $15^{\circ} \mathrm{N}$ to about $23^{\circ} \mathrm{N}$, which is characterized by steep walls and irregular bottom topography [Drake and Girdler, 1964; Coleman, 1974].

Large seafloor spreading magnetic anomalies are associated with the axial trough and have been correlated with the geomagnetic time scale from the present to $4 \mathrm{~m}$.y. B.P. or perhaps 5 m.y. B.P. [Roeser, 1975; Searle and Ross, 1975] (Figure 15). In the northern Red Sea where the axial trough is not develsped, the magnetic field is generally smooth, with occasional sharp anomalies often associated with bathymetric 'deeps.'

The identification of $10 \mathrm{~m}$.y. B.P. magnetic anomalies in the Gulf of Aden requires that motion has also occurred in the Red Sea for at least that length of time. The heavy lines parallel to the axis of the Red Sea in Figure 15 show the amount of extension that has occurred in the past $10 \mathrm{~m} . y$. using the finite rotation pole of McKenzie et al. [1970] at $36.5^{\circ} \mathrm{N}, 18^{\circ} \mathrm{E}$, which Le Pichon and Francheteau [1978] show also describes the present instantaneous motion, and assuming that the present angular rotation rate of $3.2 \times 10^{7} \mathrm{deg} / \mathrm{yr}$ has been constant over the past $10 \mathrm{~m} . \mathrm{y}$. The assumption of constant spreading 


\section{EAST SHEBA RIDGE}

TOPOGRAPHY

DAL-02
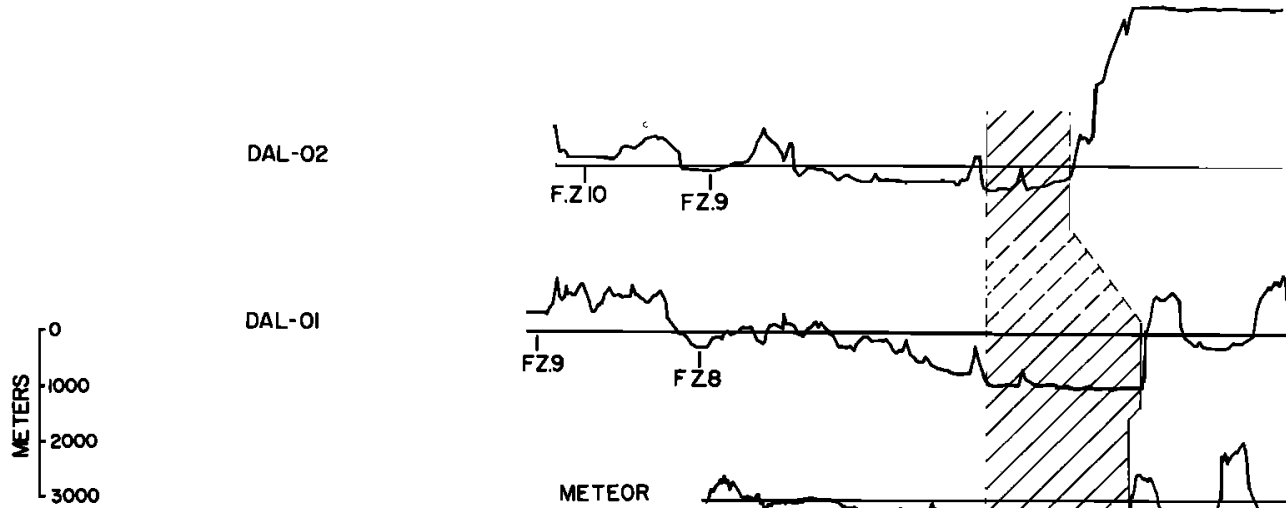

DAL-OI
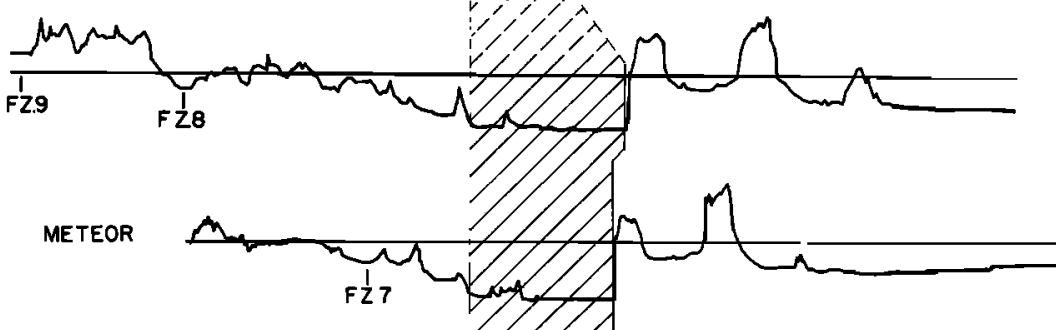

GL23-1

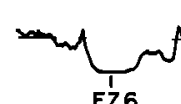

V35-03
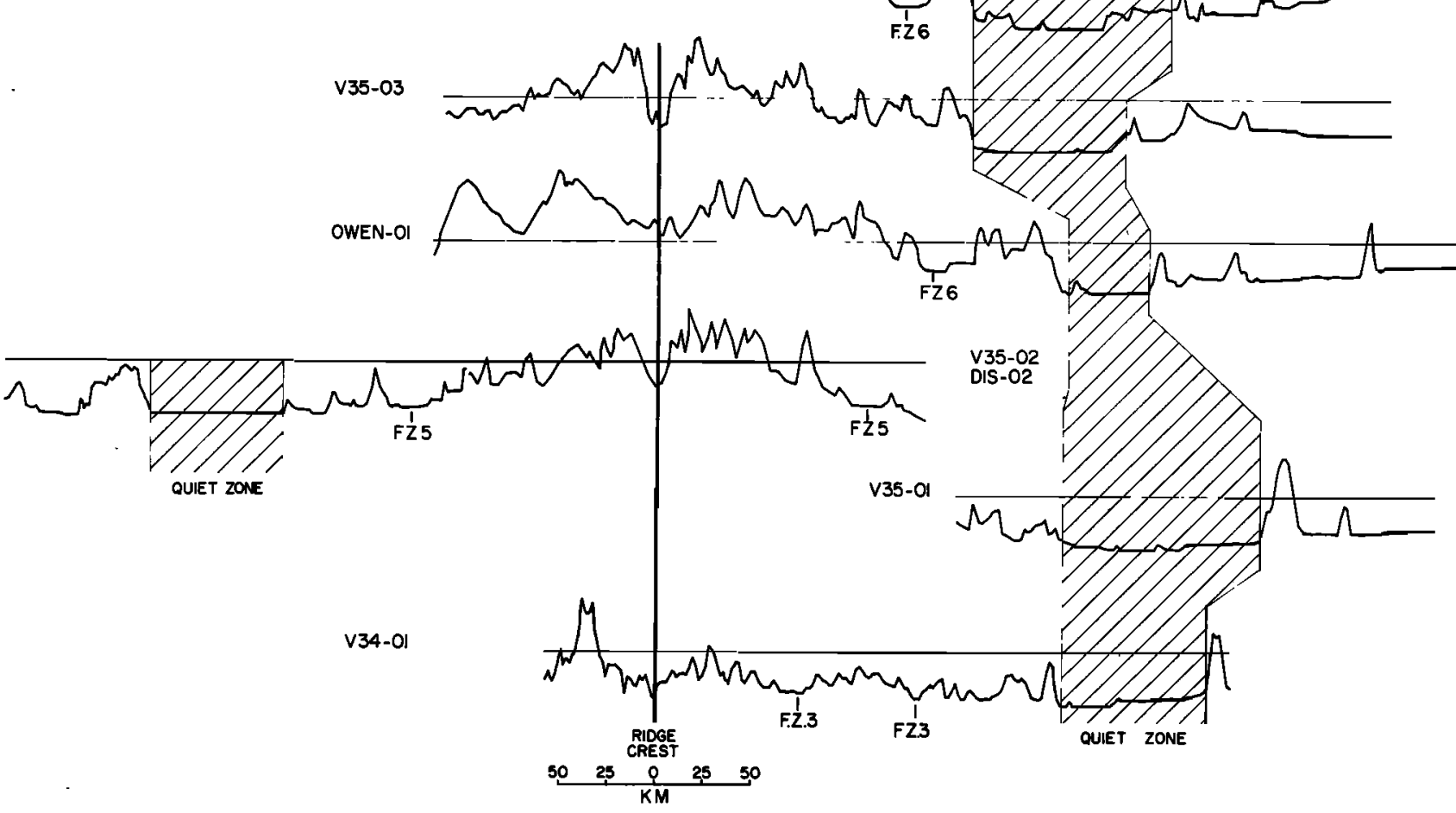

Fig. 12. Bathymetry profiles across the East Sheba Ridge, showing the magnetic quiet zone, Sharbithat Ridge, and Error Ridge. Lacation of profiles is shown in Figure 2 . All profiles have been projected along $\mathrm{N} 32^{\circ} \mathrm{E}$. Horizontal reference lines are at a depth of $3000 \mathrm{~m}$.

rates appears to be valid in the Gulf of Aden, since the instantaneous rates and directions determined by Minster et al. [1974] and Minster and Jordan [1978] agree with those predicted by the McKenzie et al. [1970] finite rotation pole, and thus the assumption is valid in the Red Sea to the uncertainty introduced by the East African Rift. This rotation of $3.2^{\circ}$ about the pole then represents the minimum amount of extension that must have occurred in the Red Sea.

An estimate of the total amount of opening in the Red SeaGulf of Aden system can be made from the $105 \mathrm{~km}$ of postCretaceous shear, which has been documented by Quennell [1958] and Freund et al. [1970], on the Dead Sea Rift. As was pointed out by McKenzie et al. [1970], some opening in the
Gulf of Suez (implying the existence of a 'Sinai plate') is necessary, because the Levant Shear does not fall on a small circle about the Red Sea pole. The shore to shore fit of the Red Sea by McKenzie et al. [1970] requires $60-90 \mathrm{~km}$ of opening in the Gulf of Suez. This figure has been questioned on geological grounds, and Freund [1970] estimates that 25-30 $\mathrm{km}$ of opening could have occurred in the Gulf of Suez.

If a figure of $135 \mathrm{~km}$ of motion is accepted for the Red Sea at the latitude of the Gulf of Aqaba where it intersects the Levant Shear, this results in a rotation of $4.34^{\circ}$ about the Red Sea pole at $36.5^{\circ} \mathrm{N}, 18^{\circ} \mathrm{E}$. The amount of opening implied by this rotation for the central and southern Red Sea is shown as a dashed line in Figure 15. The total opening calculated at 

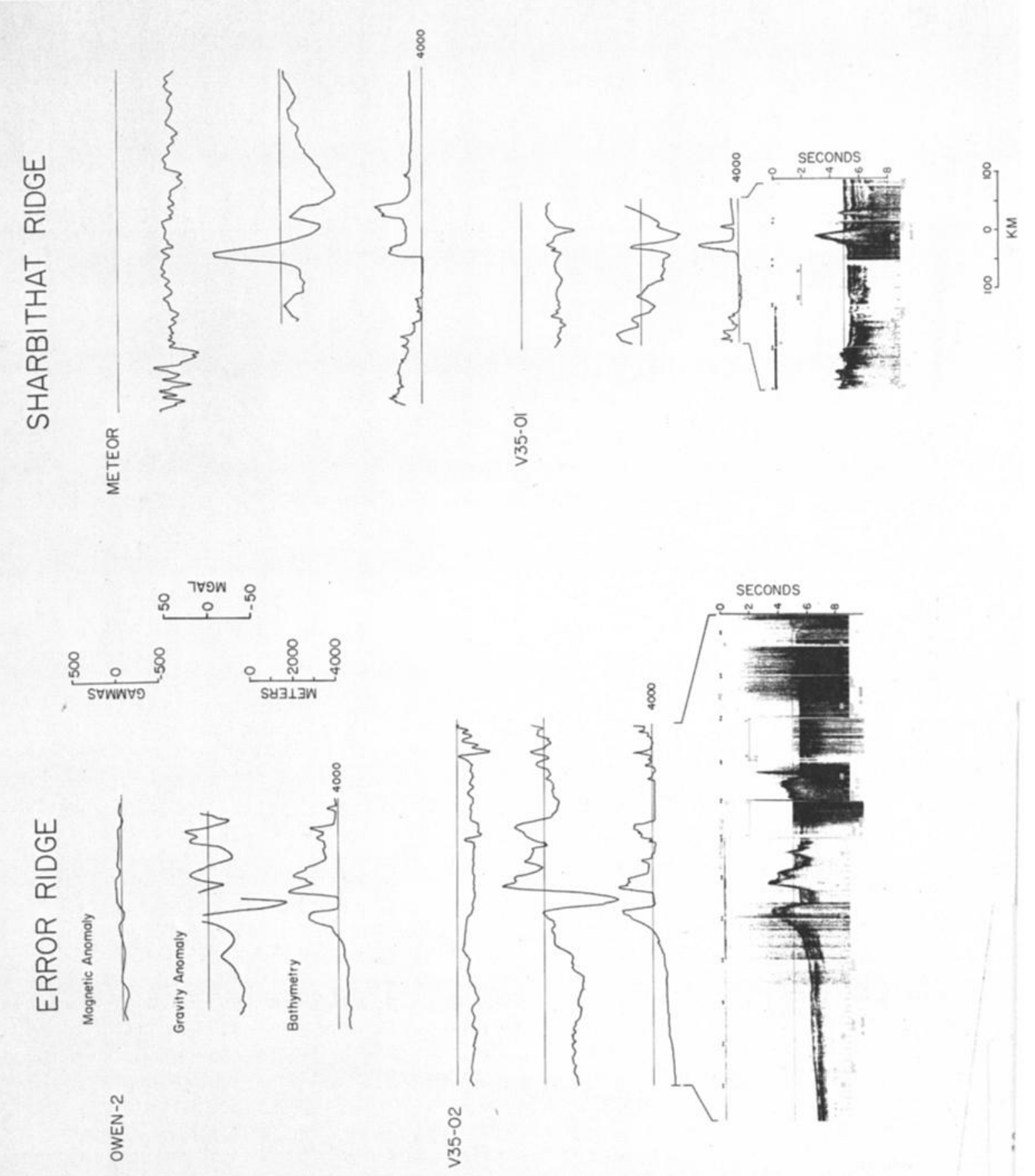


\section{GL23-3}

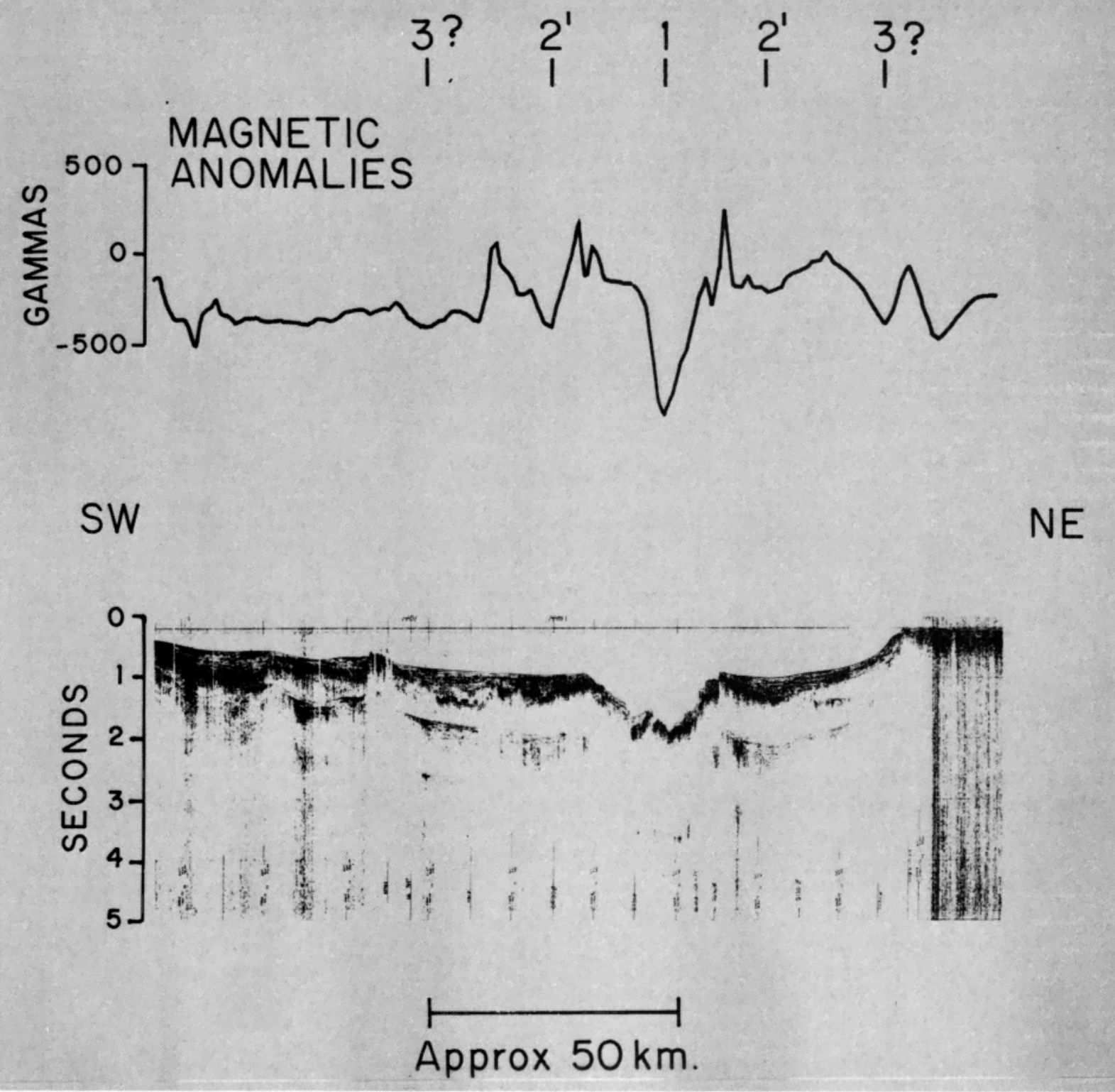

Fig. 14. Seismic reflection and total intensity magnetic anomaly profiles along line GL23-3 in the western Gulf of Aden. Numbers over the magnetic anomalies are correlations with the geomagnetic reversal sequence (Figure 6). Location is shown in Figure 2.

$17^{\circ} \mathrm{N}$, where magnetic anomalies out to 4 or 5 m.y. B.P. have been identified by Roeser [1975], is $225 \mathrm{~km}$. The seafloor spreading magnetic anomalies record $80-85 \mathrm{~km}$ of motion, implying that $140-145 \mathrm{~km}$ of extension occurred prior to the generation of the magnetic anomaly sequence and the creation of the axial rift.

As a check on the validity of using the Levant Shear to measure opening in the Red Sea, the $45 \mathrm{~km}$ of post-Miocene motion measured on the Dead Sea Rift by Freund et al. [1970] implies $75 \mathrm{~km}$ of extension at $17^{\circ} \mathrm{N}$ in the Red Sea, while the measured distance between the 5-m.y. isochrons on Roeser's [1975] chart is $83 \mathrm{~km}$. The two figures are in very reasonable agreement, particularly since there may be an additional contribution from the Gulf of Suez.

The opening prior to the creation of the axial trough could have occurred at a localized spreading center, in which case the area within the dashed lines would be expected to be oceanic crust, or it could have occurred in a diffuse manner, in which case attenuated or altered continental crust would be expected under the main trough. Seismic refraction lines in the main trough [Drake and Girdler, 1964; Tramontini and Davies, 1969] give main crustal layer velocities that range from $5.91 \mathrm{~km} / \mathrm{s}$ to $6.97 \mathrm{~km} / \mathrm{s}$ and have been interpreted as implying both continental-type rocks [Drake and Girdler, 1964; Coleman, 1974] and oceanic basement [Tramontini and Davies, 1969; McKenzie et al., 1970; Girdler and Styles, 1974].

The thick Miocene salt deposits that underlie the main trough prevent direct observation of basement, except under the axial trough where it is known to be oceanic. Seismic reflection studies [Knott et al., 1966; Phillips and Ross, 1970] 
show the upper surface of the evaporites to be faulted and that the faulting is most severe in an area about $100 \mathrm{~km}$ wide in the center of the main trough, but extends completely across the main trough. Also, the deformation continues up through the overlying sediments, giving the floor of the main trough its irregular, broken appearance.

This observation suggests that deformation in the northern Red Sea, where there is no axial trough, is occurring over an area at least $100 \mathrm{~km}$ wide. This wide zone of deformation suggests that the extension that must be taking place there is also spread throughout the $100-\mathrm{km}$-wide region, probably through a combination of dike injection and faulting, such as that found in Afar. If it is assumed that opening has been confined to the main rift valley, then at $17^{\circ} \mathrm{N}$, where the rift boundary escarpments are now about $415 \mathrm{~km}$ apart, $140 \mathrm{~km}$ of extension occurred prior to the initiation of seafloor spreading in a region originally $190 \mathrm{~km}$ wide, which is a $75 \%$ finite strain. At 25-N, where the axial trough has not developed, $160 \mathrm{~km}$ of diffuse extension has occurred within a presently $280-\mathrm{km}$-wide rift, implying a finite extension of $133 \%$.

Again assuming that the poles and opening rates have remained stable, an opening of $135 \mathrm{~km}$ for the northern end of the Red Sea implies that $79 \mathrm{~km}$ of diffuse extension occurred near the Alula Fartak fracture zone prior to the initiation of seafloor spreading at anomaly 5 time. Subtracting the $220 \mathrm{~km}$ of oceanic crust from the $420-\mathrm{km}$ width of the rift results in the conclusion that $79 \mathrm{~km}$ of extension occurred in an area presently $200 \mathrm{~km}$ wide, implying a $65 \%$ strain. In the western Gulf of Aden where seafloor spreading has only been active to 3-4 m.y., the same calculation implies about $200 \%$ strain.

\section{Origin of the Magnetic Quiet Zone}

The model for the development of a rifted continental margin, which is suggested by data from the Gulf of Aden and the Red Sea, involves an initial period of extension prior to the development of an organized mid-ocean ridge. Opening of the order of $100 \mathrm{~km}$ can occur during this period, which in the Gulf of Aden and Red Sea lasted from 10 to $25 \mathrm{~m}$.y. We suggest that this opening occurred by diffuse extension involving dike injection and rotational, normal faulting within a wide rift valley environment, followed by the concentration of extension and volcanism along a well-defined axis. The area affected by the initial stage of diffuse extension represents the magnetic quiet zone or zone of uncorrelatable anomalies, which are a ubiquitous feature of rifted continental margins.

Diffuse extension within the magnetic quiet zone is suggested by seismic reflection profiles of the continental margin of the Bay of Biscay [de Charpal et al., 1978; Montadert et al., 1979] and of southeastern Baja California [Normark and Curray, 1968] that show structures interpreted as blocks of continental basement that have been faulted and rotated on listric faults. Rotational faults in the form of half grabens have also been observed in the continental crust under the continental shelf of Nova Scotia [Given, 1977].

Similar structures have been observed under the quiet zone of the southern margin of Australia, but there they have been interpreted as indicating primarily vertical rather than horizontal motion [Falvey, 1974; Bouef and Doust, 1975; Deighton et al., 1976; Talwani et al., 1978] partly because of the long time interval between the formation of the rift in the MidCretaceous and the onset of seafloor spreading in the Lower Eocene. Estimates of the amount of extension on the normal faults range from negligible [Talwani et al., 1978] to 15-20\% [Montadert et al., 1979], much less than the 65-200\% suggested here. However, the crustal thinning found necessary by Watts and Steckler [1979] to explain the tectonic component of the subsidence at deep wells on the eastern margin of North America implies 50\% extension at the Oneida 0-25 well and $200 \%$ extension at the Cost B-2, well in agreement with my estimate.

Also, Morton and Black [1975] estimate 50\% crustal thinning, implying $100 \%$ extension, from analysis of rotated fault blocks around the margins of Afar. This figure is consistent with Kürsten's [1972, 1975] observation of between $12 \%$ and $30 \%$ extension in a 5-m.y.-old horizon in the Danakil Depression if opening rates have been relatively constant over much of the time since rifting began 20-25 m.y. B.P.

An entirely different origin has been suggested for the production of a magnetic quiet zone on the basis of data from the Gulf of California, where the apparently oceanic [Phillips, 1964; Harrison and Mathur, 1964] basins in the central part of the Gulf show no obvious pattern of magnetic lineations [Hilde, 1964; Larson et al., 1972], while a mid-ocean ridge with magnetic anomalies to $4 \mathrm{~m}$.y. B. P. is present at the mouth of the gulf [Larson et al., 1968; Moore and Buffingham, 1968]. This has been explained in terms of rapid sedimentation, which has kept the spreading center buried and thus altered the normally extrusive accretion process into an intrusive process resulting in the creation of sills rather than dikes [Larson et al., 1972].

The main requirement for such a mechanism is that the sedimentation rate be great enough that the ridge axis is continually buried by enough sediments that dikes fail to reach the surface, but rather form sills within the sediments. This is quite reasonable for the central Gulf of California, which has experienced extraordinary sedimentation rates (greater than $1200 \mathrm{~m} / \mathrm{m} . y$.$) [Shipboard Scientific Party, 1979]. The sedi-$ mentation rate immediately above basement at site 231 in the magnetic quiet zone in the Gulf of Aden is $47.8 \mathrm{~m} / \mathrm{m}$.y. [Shipboard Scientific Party, 1974]. These sediments have been dated at 12.5-12.8 m.y. B.P. and thus predate the formation of lineated magnetic anomalies by about $2 \mathrm{~m}$.y. This sedimentation rate is slightly above the worldwide average [Berger, 1974] but is well within the range of present sedimentation rates found, for example, in the North Atlantic [McIntyre et al., 1972] where mid-ocean ridge tectonics are undisputedly occurring at comparable spreading rates. Also, the basaltic basement underlying the sediments at site 231 appears to be extrusive in origin [Dmitriev and Fisher, 1974].

The only area in the Gulf of Aden in which reported sedimentation rates even approach those of the Gulf of California is the far western portion, where Olausson and Olsson [1969] describe a core taken at $11^{\circ} 57^{\prime} \mathrm{N}, 44^{\circ} 18^{\prime} \mathrm{E}$ in which they find sedimentation rates of the order of $1000 \mathrm{~m} / \mathrm{m}$.y. in an $11-\mathrm{m}$ long core. Thus while intrusive sea floor spreading might have been possible in the extreme western end of the Gulf of Aden, it appears that the sedimentation rates in the central and eastern Gulf were not sufficient to produce such a mechanism.

Also, it should be pointed out that Moore [1973] found that the motion recorded by seafloor spreading magnetic anomalies in the mouth of the Gulf of California is not sufficient to explain the observed separation and stated that a 'proto-gulf' is necessary. The region of the proto-gulf at the tip of Baja California, where the basement structures are visible consists 


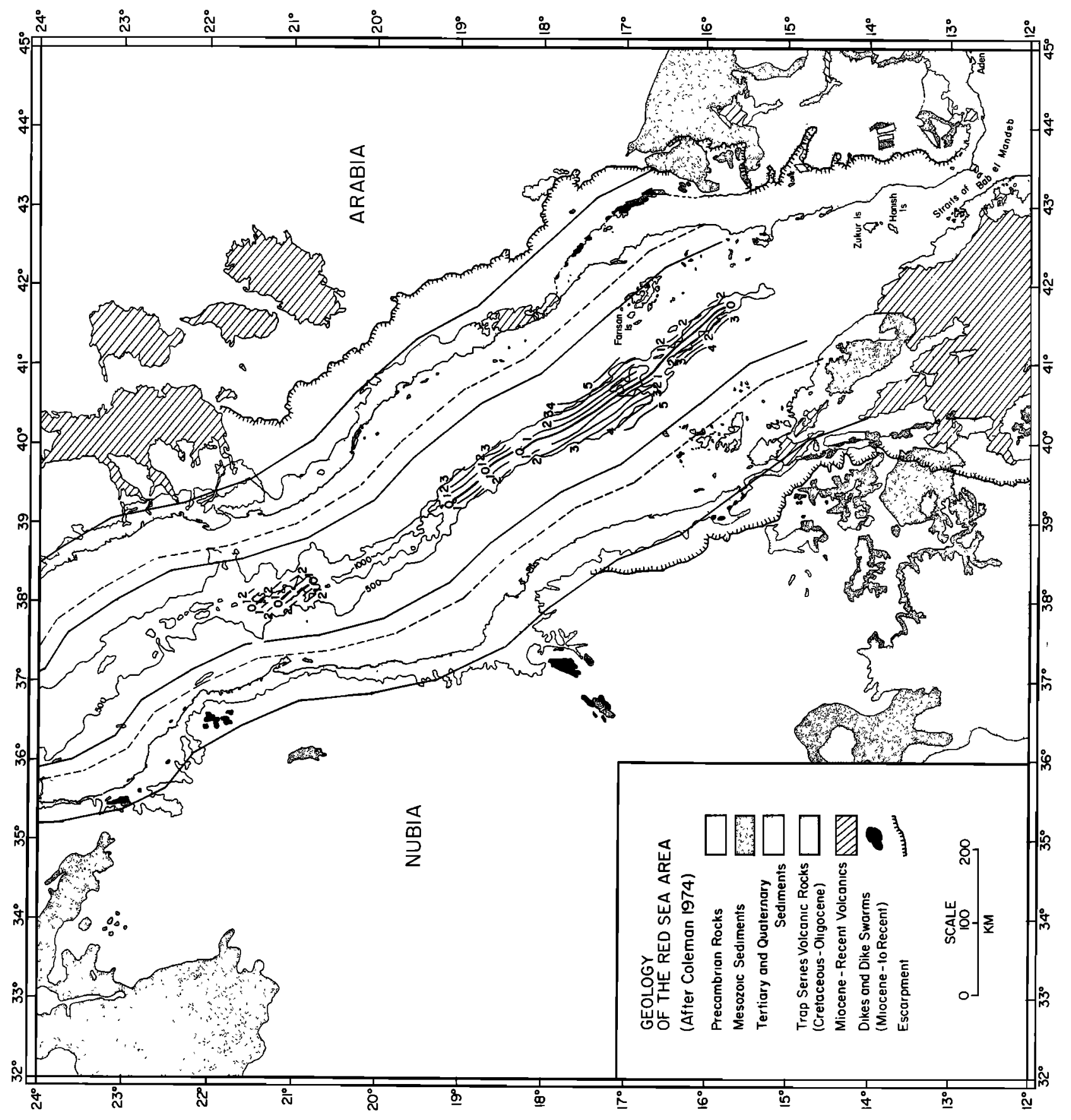


of normally faulted granitic rocks [Normark and Curray, 1968; Shipboard Scientific Party, 1979] similar to what is observed under many quiet zones. It thus appears that there could be a region of diffuse extension landward of the area in which intrusive seafloor spreading is occurring.

\section{Formation of the Gulf of Aden Rift}

The earliest signs of the formation of the Gulf of Aden are found in the Oligocene, when most of the Horn of Africa became emergent, and Oligocene sediments are found in discontinuous patches along the eastern portion of the margin of the Gulf of Aden. Azzaroli [1968, p. 132] describes the Gulf of Aden as being 'a shallow embayment surrounded by almost flat land' at that time.

The faulting responsible for the formation of the Gulf of Aden rift has been dated as early Miocene (Aquitanian-Burdigalian, approximately 20-22 m.y. B.P.) by Somaliland Oil Exploration Co. [1954] and Azzaroli and Fois [1964] and as Oligocene and Miocene by Beydoun [1966]. The Gulf of Aden rift was blocked out by high-angle normal faulting that not only formed the down-faulted rift valley but also uplifted the surrounding regions to form the elevated plateau that flank the Gulf of Aden [Somaliland Oil Exploration Co., 1954; Beydoun, 1970].

The Gulf of Aden rift thus did not form on top of a large broad dome, presumably of thermal origin, as has been widely 'proposed in models of continental rifting [e.g., Dewey and Bird, 1970; Falvey, 1974]. The volcanism at the Afar hot spot began about $40 \mathrm{~m}$.y. prior to rifting but had very little effect on the area of the future Gulf of Aden rift, which remained near or slightly below sea level until the initiation of rifting. The great uplift of the Northern Somalian and Southern Arabian plateau occurred simultaneously with the faulting. It thus appears that the rift was pulled apart in a passive manner rather than being pushed apart from a series of hot spots as is suggested, for example, by Kinsman [1975] and Burke [1976]. The role played by the Afar hot spot apparently was to determine the location of the tear and to serve as a corner between the east-west rift of the Gulf of Aden and north-south rift of the Red Sea.

A speculative explanation for the separation of Arabia from Africa can be found in the development of the Indian Ocean. During the Upper Cretaceous and early Tertiary, India moved rapidly northward across the Tethys, creating the present Indian Ocean in its wake. India and Eurasia came into contact in the early Eocene, as indicated by a flood of Eurasian granitic detritus into the Gondwana miogeosyncline in Pakistan [Stoneley, 1974]. At this time, the rapid northward motion of India ceased, and spreading nearly ceased on the Carlsberg Ridge. The last anomaly of the early Tertiary sequence found in the Arabian Sea by McKenzie and Sclater [1971] is anomaly 23, which marks the Paleocene-Eocene boundary (about 55 m.y. B.P. [LaBrecque et al., 1977]), al-

Fig. 15. (Opposite) Geology of the Red Sea area and amount of opening implied from various lines of reasoning. The lines over the axial trough are magnetic isochrons in millions of years before present (m.y. B.P.) from Roeser [1975] and Searle and Ross [1975]. The solid lines show $3.2^{\circ}$ and $8^{\circ}$ of opening about the McKenzie et al. [1970] pole at $36.5^{\circ} \mathrm{N}, 18^{\circ} \mathrm{E}$, centered at the axis of the Red Sea and correspond to opening of the Gulf of Aden to the 10-m.y. isochron and to the rift-bounding faults. The dashed line represents the amount of opening determined by assuming $105 \mathrm{~km}$ of offset along the Dead Sea Rift and $30 \mathrm{~km}$ of opening in the Gulf of Suez. though anomalies through anomaly 20 (Mid-Eocene, about 45 m.y. B.P.) may be present (B. R. Naini, personal communication, 1979).

After a period of reorganization, India began to move northward again although at a much slower rate. Bathymetric evidence on the Carlsberg Ridge suggests that this occurred '20-30 m.y. B.P. [McKenzie and Sclater, 1971; Anderson et al., 1977]. This date is in agreement with the observation that compressive tectonics in the Himalayas began in the Late Oligocene [Stoneley, 1974].

The renewed northward motion of India coincides in time with the Gulf of Aden rifting and allows the speculation that during the reorganization period, the Owen fracture zone, which had connected the Carlsberg Ridge with the now defunct Tethys, became locked, and when spreading began again on the Carlsberg Ridge, Arabia was torn off of Africa and carried northward.

An argument against this hypothesis is that the Owen fracture zone is mildly active seismically north of the Sheba Ridge, which means that relative motion is occurring between the Arabian and Indian plates. A focal mechanism solution by Banghar and Sykes [1969] shows right lateral strike slip motion across the Owen fracture zone. This implies that Arabia is moving northward more rapidly than India, which would not be expected if it were being dragged northward by India. Banghar and Sykes [1969] state that their solution is not of a high quality and that a great deal of emphasis should not be placed on it. However, it does remain the only direct observation of the relative motion between India and Arabia.

\section{Indian Ocean Poles of Rotation}

The motion between India and Arabia determined by McKenzie and Sclater [1971] from the Arabia-Somalia pole of Le Pichon [1968] and the India-Somalia pole of Fisher et al. [1971] implies $1.5 \mathrm{~cm} / \mathrm{yr}$ of slip along the Owen Fracture zone. This cannot be correct, since the total opening rate of $2.8 \mathrm{~cm} / \mathrm{yr}$ for East Sheba Ridge and that of $2.4-2.6 \mathrm{~cm} / \mathrm{yr} \mathrm{ob}-$ served by McKenzie and Sclater for the western Carlsberg Ridge differ by at most about $0.4 \mathrm{~cm} / \mathrm{yr}$. The difficulty arises from the fact that the India-Somalia pole determined by Fisher et al. [1971] at $16^{\circ} \mathrm{N}, 48^{\circ} \mathrm{E}$ is only about $10^{\circ}$ from the Owen Fracture Zone, resulting in a predicted total spreading rate of only $1.2 \mathrm{~cm} / \mathrm{yr}$ on the western end of the Carlsberg Ridge (Table 2). The global solutions of Minster et al. [1974] and Minster and Jordan [1978] predict about $0.7 \mathrm{~cm} / \mathrm{yr}$ of slip on the Owen fracture zone, which is closer to what is observed, but the improvement results from the fact that the spreading rates of both the East Sheba Ridge and Carlsberg Ridge are underestimated in those models. They both predict a total opening rate of $1.6 \mathrm{~cm} / \mathrm{yr}$ for the western end of the Carlsberg Ridge, much less than the observed value.

The reason that the pole in all of these solutions is so close to the Owen fracture zone is that there is a large difference in the strike of fracture zones on the Carlsberg Ridge and the Central Indian Ridge (Table 2). Fracture zone azimuths on the Carlsberg Ridge are in the range $30^{\circ}-40^{\circ}$, while those on the Central Indian Ridge are about $60^{\circ}$. A pole which is further away than those that have been proposed cannot account for this change in azimuth.

However, the observed spreading rates in the vicinity of the Owen fracture zone require that the pole be further away. Table 2 shows the spreading rates and fracture zone azimuths calculated from a pole at $26^{\circ} \mathrm{N}, 40^{\circ} \mathrm{E}$ that predicts spreading 


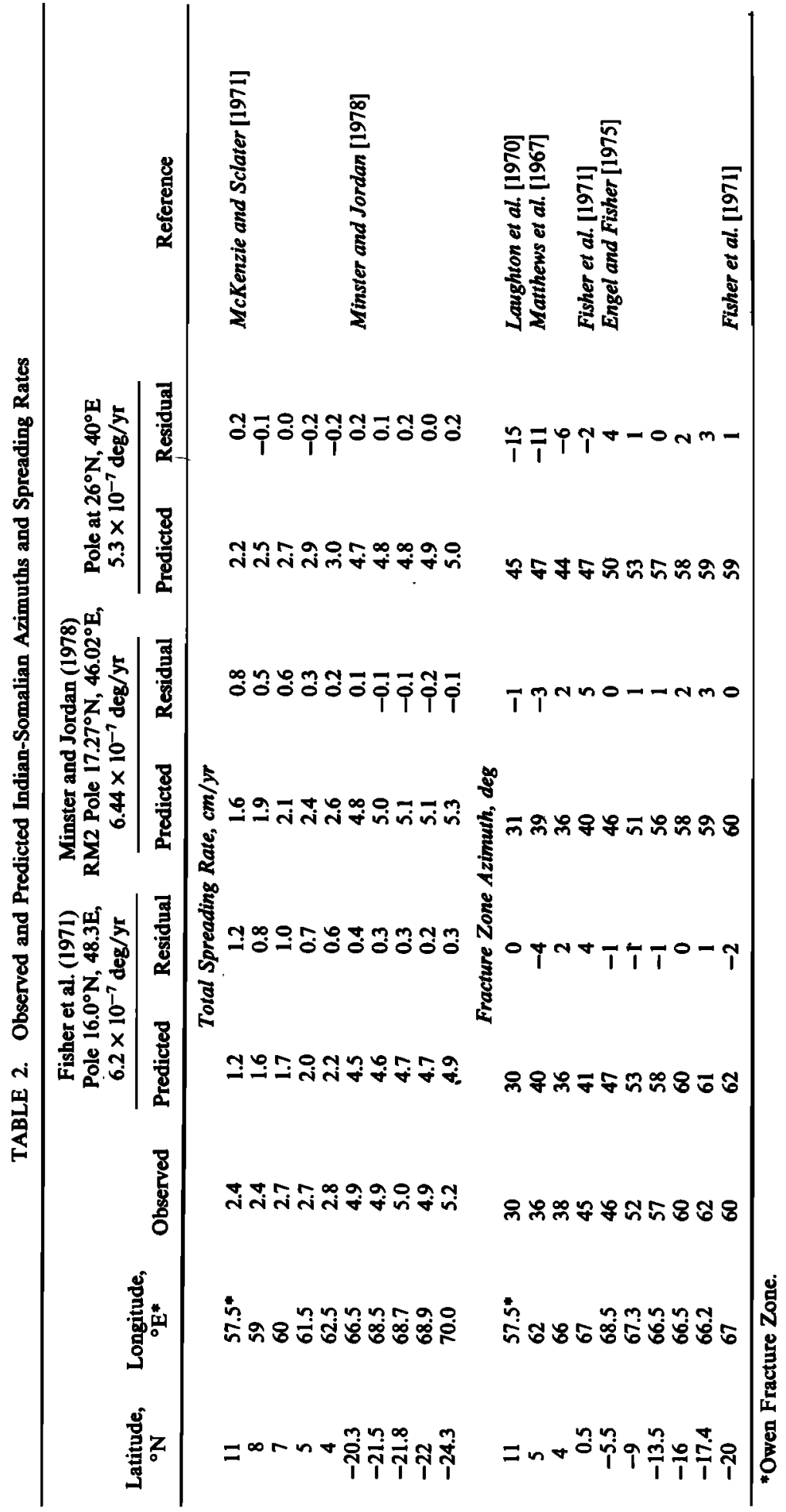


rates and azimuths on the Central Indian Ridge as accurately as the poles of Fisher et al. [1971] and Minster and Jordan [1978] and predicts the spreading rates on the Carlsberg Ridge much better than do the others. However, the fracture zone azimuths on the Carlsberg Ridge are off by as much as $15^{\circ}$. This requires a very large 'leaky' component of extension in the Carlsberg Ridge fracture zones. The nature of the Owen fracture zone is not inconsistent with a component of extension across it. The fracture zone is $50-100 \mathrm{~km}$ wide and contains a large transverse ridge made up of ultramafic rocks, which Bonatti and Hamlyn [1978] conclude originated at a depth of $25 \mathrm{~km}$ in the upper mantle. A small amount of extension across the fracture zone could have allowed the emplacement of the ultramafic body.

An alternative explanation is that the Indian plate is not behaving coherently, and thus it is not appropriate to use a single pole to describe motion on the Carlsberg and Central Indian ridges. This possibility is suggested by a belt of earthquake epicenters [Sykes, 1970] and deformed sediments [Eittreim and Ewing, 1972; Weissel et al., 1979] that stretches from the Chagos-Laccadive Ridge to the Ninetyeast Ridge.

\section{CONCLUSIONS AND SUMmary}

1. Magnetic anomaly data from the eastern Gulf of Aden and the East Sheba Ridge show a clear sequence of seafloor spreading anomalies from the axial anomaly to anomaly 5 (10 m.y. B. P.). The data from the western Gulf of Aden are less clear but can be reasonably interpreted to be consistent with the data further east. The good fit to the observed magnetic anomalies obtained by Girdler and Styles [1978] by using a two-stage spreading history results not from the portion of the time scale that they chose, but from special assumptions they made, resulting in a history that is both complicated and differs significantly on two profiles $\mathbf{4 0} \mathbf{~ k m}$ apart.

2. A 'magnetic quiet zone' is located beyond anomaly 5 on the Sheba Ridge. This consists of an area of either very low amplitude magnetic relief or of uncorrelatable magnetic anomalies. The boundary between the seafloor spreading magnetic anomalies and the magnetic quiet zone is also a major structural boundary. The crust in the quiet zone is slightly deeper than on the ridge flank and does not have a topographic gradient across it, suggesting that it was not generated by spreading at an organized mid-ocean ridge. The landward edge of the magnetic quiet zone is marked by a major fault escarpment that separates the quiet zone crust from the uplifted plateaux of southern Arabia and northern Somalia.

A magnetic quiet zone and the associated structures are present not only where Sheba Ridge separates the continental lithosphere of Arabia and Africa, but also on the eastern part of the East Sheba Ridge where it separates the older oceanic lithosphere of the Owen and Somali basins. Here the position occupied by the continental margin within the Gulf of Aden is taken by ridge complexes that stretch from the edge of the continents to the Owen fracture zone. These ridges have no magnetic anomaly associated with them, and a large negative gravity anomaly occurs over their outer portion.

3. Seafloor spreading magnetic anomalies are only present to anomaly $2^{\prime}$ ( $3 \mathrm{~m}$.y. B.P.) or anomaly 3 (4 m.y. B.P.) to the west of $45^{\circ} \mathrm{E}$ in the Gulf of Aden, although extension must have been occurring for at least $10 \mathrm{~m}$.y. Similarly, magnetic anomaly sequences out to 4 or $5 \mathrm{~m}$.y. B.P. are present over the axial trough in the central Red Sea, while to the north, both axial trough and seafloor spreading magnetic anomalies are not present. The amount of motion recorded along the Levant Shear and in the Gulf of Suez imply that from $80 \mathrm{~km}$ to about $160 \mathrm{~km}$ of opening occurred in the Gulf of Aden and Red Sea prior to the formation of lineated magnetic anomalies and mid-ocean ridge topography. It is suggested that this opening occurred by diffuse extension over an area $100 \mathrm{~km}$ or more wide. The amount of diffuse extension determined for the Gulf of Aden and Red Sea implies $65 \%$ to $200 \%$ extension of the original rift valley prior to the initiation of seafloor spreading at a discrete spreading center.

4. The faulting responsible for the Gulf of Aden rift began in the late Oligocene or early Miocene, and the uplift of the plateaux flanking the Gulf of Aden occurred during the main episode of faulting. The Gulf of Aden apparently formed passively as a 'tear' in response to forces applied elsewhere. Its formation coincides with the renewed northward motion of India in the Oligocene, suggesting that Arabia and India became nearly locked together across the Owen fracture zone during the reorganization following the initial collision of India and Eurasia and that the same forces responsible for the northward flight of India 'tore' Arabia off of Africa.

Acknowledgments. I thank H. A. Roeser and R. C. Searle for sending magnetics data in the Gulf of Aden region and R. B. Whitmarsh, V. Courtillot, and P. Styles for preprints of their papers prior to publication. P. D. Rabinowitz and J. K. Weissel reviewed the manuscript and offered constructive comments. This work was supported by National Science Foundation grant OCE 77-20098. Lamont-Doherty Geological Observatory Contribution number 3028.

\section{REFERENCES}

Anderson, R. N., M. G. Langseth, and J. G. Sclater, The mechanisms of heat transfer through the floor of the Indian Ocean, $J$. Geophys. Res., 82, 3391-3410, 1977.

Azzaroli, A., On the evolution of the Gulf of Aden, Int. Geol. Congr. Rep. Sess. 23rd, part 1, 125-134, 1968.

Azzaroli, A., and V. Fois, Geological outlines of the northern end of the Horn of Africa, Int. Geol. Congr. Rep. Proc. 22nd, part IV, 293314, 1964.

Banghar, A. N., and L. R. Sykes, Focal mechanisms of earthquakes in the Indian Ocean and adjacent regions, J. Geophys. Res., 74, 632$649,1969$.

Barberi, F., H. Tazieff, and J. Veret, Volcanism in the Afar Depression: Its tectonic and magmatic significance, Tectonophysics, 15, 19$29,1972 a$.

Barberi, F., S. Borsi, G. Ferrara, G. Marinelli, R. Santa Croce, H. Tazieff, and J. Veret, Evolution of the Danakill Depression (Afar, Ethiopia) in light of radiometric age determination, J. Geol., 80, 720-729, $1972 b$.

Barberi, F., G. Ferrara, R. Santa Croce, and J. Veret, Structural evolution of the Afar triple junction, in Afar Depression of Ethiopia, edited by A. Pilger and A. Rösler, pp. 38-54, Schweizerbart, Stuttgart, Germany, 1975.

Berger, W. H., Deep-sea sedimentation, in The Geology of Continental Margins, edited by C. A. Burk and C. L. Drake, pp. 213-242, Springer, New York, 1974.

Beydoun, Z. R., Geology of the Arabian Peninsula: Eastern Aden Protectorate and part of Dhufar, U.S. Geol. Surv. Prof. Pap, 560-H, 1966.

Beydoun, Z. R., Southern Arabia and northern Somalia: Comparative geology, Phil. Trans. Roy. Soc. London, Ser. A, 267, 267-292, 1970.

Beydoun, Z. R., and H. R. Bichan, The geology of Socotra Island, Gulf of Aden, Quart. J. Geol. Soc. London, 125, 413-446, 1970.

Black, R., W. H. Morton, and J. Veret, New data on Afar tectonics, Nature Phys. Sci., 240, 170-173, 1972.

Boeuf, M. G., and H. Doust, Structure and development of the southern margin of Australia, Aust. Pet. Explor. Assoc. J., 15, 33-43, 1975.

Bonatti, E., and P. R. Hamlyn, Mantle uplifted block in the western Indian Ocean, Science, 201, 249-251, 1978.

Burke, K., Development of graben associated with the initial ruptures 
of the Atlantic Ocean, Tectonophysics, 36, 93-112, 1976.

Christiansen, T. B., H.-U. Schaefer, and M. Schönfeld, Geology of southern and central Afar, Ethiopia, in Afar Depression of Ethiopia, edited by A. Pilger and A. Rösler, pp. 259-277, Schweizerbart, Stuttgart, Germany, 1975.

Civetta, L., M. DeFino, P. Gosparini, M. R. Ghiara, L. LaVolpe, and L. Lirer, Geology of central-eastern Afar (Ethiopia), in Afar Depression of Ethiopia, edited by A. Pilger and A. Rösler, pp. 201-205, Schweizerbart, Stuttgart, Germany, 1975.

Coleman, R. G., Geologic background of the Red Sea, in Initial Reports of the Deep-Sea Drilling Project, vol. 23, edited by R. B. Whitmarsh, O. E. Weser, D. A. Ross et al., pp. 813-820, U.S. Govemment Printing Office, Washington, D. C., 1974.

Courtillot, V., A. Galdeano, and J. L. Le Mouel, Propagation of an accreting plate boundary: $A$ discussion of new aeromagnetic data in the Gulf of Tadjourah and southern Afar, Earth Planet Sci. Lett., 47, 144-160, 1980.

de Charpal, O., P. Guennoc, L. Montadert, and D. G. Roberts, Rifting, crustal attenuation and subsidence in the Bay of Biscay, $\mathrm{Na}$ ture, 275, 706-711, 1978.

Deighton, I., D. A. Falvey, and D. J. Taylor, Depositional environments and geotectonic framework: Southern Australian continental margin, Aust. Pet. Explor. Assoc. J., 16, 25-36, 1976.

Dewey, J. F., and J. M. Bird, Mountain belts and the new global tectonics, J. Geophys. Res., 75, 2625-2647, 1970.

Dmitriev, L. V., and R. L. Fisher, Appendix A: Preliminary observations on the igneous rocks sampled at Site 231, in Initial Reports of the Deep-Sea Drilling Project, vol. 24, edited by R. L. Fisher, E. T. Bunce et al., pp. 31-34, U.S. Government Printing Office, Washington, D. C., 1974.

Drake, C. L., and R. W. Girdler, A geophysical study of the Red Sea, Geophys. J. Roy. Astron. Soc., 8, 473-495, 1964.

Eittreim, S. L., and J. Ewing, Mid-Plate tectonics in the Indian Ocean, J. Geophys. Res., 77, 6413-6421, 1972.

Embleton, B. J. J., and D. A. Valencio, Paleomagnetism and the reconstruction of Gondwanaland, Tectonophysics, 40, 1-12, 1977.

Engel, L. G., and R. L. Fisher, Granitic to ultramafic rock complexes of the Indian Ocean ridge system, Western Indian Ocean, Bull. Geol. Soc. Amer., 86, 1553-1578, 1975.

Falvey, D. A., The development of continental margins in plate tectonic theory, Aust. Pet. Explor. Assoc. J., 14, 95-106, 1974.

Farquharson, W. I., Topography with an appendix on magnetic observations, in The John Murray Expedition, 1933-34, The Scientific Reports, Introduction and Topography, vol. 1, pp.43-61, British Museum of Natural History, London. 1936.

Fisher, R. L., J. G. Sclater, and D. P. McKenzie, Evolution of the Central Indian Ridge, Western Indian Ocean, Bull. Geol. Soc. Am., $82,553-562,1971$.

Francis, T. J. B., D. Davies, and M. N. Hill, Crustal structure between Kenya and the Seychelles, Phil. Trans. Roy. Soc. London, Ser. A, 259, 240-261, 1966.

Freund, R., Plate tectonics of the Red Sea and East Africa, Nature, 228, 453, 1970.

Freund, R., Z. Garfunkel, I. Zak, M. Goldberg, T. Weissbrod, and B. Derin, The shear along the Dead Sea rift, Phil. Trans. Roy. Soc. London, Ser. A, 267, 107-130, 1970.

Girdler, R. W., and P. Styles, Two stage Red Sea floor spreading, Nature, 247, 1-11, 1974.

Girdler, R. W., and P. Styles, Seafloor spreading in the western Gulf of Aden, Nature, 271, 615-617, 1978.

Given, M. M., Mesozoic and Early Cenozoic geology of offshore Nova Scotia, Bull. Can. Pet. Geol., 25, 63-91, 1977.

Harrison, C. G. A., E. Bonatti, and L. Stieltjes, Tectonism of axial valleys in spreading centers, in Afar Depression of Ethiopia, edited by A. Pilger and A. Rösler, pp. 178-198, Schweizerbart, Stuttgart, Germany, 1975.

Harrison, J. C., and S. P. Mathur, Gravity anomalies in Gulf of California, in Marine Geology of the Gulf of California, edited by $\mathrm{Tj}$. Van Andel and G. G. Shor, Am. Assoc. Pet. Geol. Mem., 3, 76-89, 1964.

Hilde, T. W. C., Magnetic profiles across Gulf of California, in Marine Geology of the Gulf of California, edited by Tj. Van Andel and G. G. Shor, Am. Assoc. Pet. Geol. Mem., 3, 122-125, 1964.

Kinsman, D. J. J., Rift valley basins and sedimentary history of trailing continental margins, in Petroleum and Global Tectonics, edited by A. G. Fisher and S. Judson, pp. 83-128, Princeton University Press, Princeton, N. J., 1975.
Knott, S. T., E. T. Bunce, and R. L. Chase, Red Sea seismic reflection studies, in The World Rift System, Geol. Surv. Can. Spec. Pap., 6614, 78-97, 1966.

Kürsten, M. Q. C., Tektonik, Salz and Vulkanismus in der DanakilSenke Äthiopiens, Geol. Jahrb., 90, 397-414, 1972.

Kürston, M. Q. C., Tectonic inventory of the Danakil Depression, in Afar Depression of Ethiopia, edited by A. Pilger and A. Rösler, pp. 170-174, Schweizerbart, Stuttgart, Germany, 1975.

LaBrecque, J. L., D. V. Kent, and S. C. Cande, Revised magnetic polarity time scale for Late Cretaceous and Cenozoic time, Geology, 5, 330-335, 1977.

Larson, P. A., J. D. Mudie, and R. L. Larson, Magnetic anomalies and fracture zone trends in the Gulf of California, Geol. Soc. Am. Bull., 83, 3361-3368, 1972.

Larson, R. L., H. W. Menard, and S. M. Smith, Gulf of California: A result of ocean floor spreading and transform faulting, Science, 161, 781-784, 1968.

Laughton, A. S., The Gulf of Aden, Phil. Trans. Roy. Soc. London, Ser. A., 259, 150-171, 1966a.

Laughton, A. S., The Gulf of Aden in relation to the Red Sea and the Afar depression of Ethiopia, in The World Rift System, Geol. Surv. Can. Spec. Pap., 66-14, 78-97, 1966 b.

Laughton, A. S., and C. Tramontini, Recent studies of the crustal structure of the Gulf of Aden, Tectonophysics, 8, 359-375, 1969.

Laughton, A. S., R. B. Whitmarsh, and M. T. Jones, The evolution of the Gulf of Aden, Phil. Trans. Roy. Soc. London, Ser. A, 267, 227266, 1970.

Le Pichon, X., Sea-floor spreading and continental drift, J. Geophys. Res., 73, 3661-3697, 1968.

Le Pichon, X., and J. Francheteau, A plate-tectonic analysis of the Red Sea-Gulf of Aden area, Tectonophysics, 46, 369-406, 1978.

Matthews, D. H., The Owen fracture zone and the northern end of the Carlsberg Ridge, Phil. Trans. Roy. Soc. London, Ser. A, 259, 172197, 1966.

Matthews, D. H., C. A. Williams, and A. S. Laughton, Mid-Ocean ridge in the mouth of the Gulf of Aden, Nature, 215, 1052-1053, 1967.

McIntyre, A., W. F. Ruddiman, and R. Jantzen, Southward penetrations of the North Atlantic Polar Front: Faunal and floral evidence of large-scale surface water mass movement over the last 225,000 years, Deep-Sea Res., 19, 61-77, 1972.

McKenzie, D. P., and J. G. Sclater, The evolution of the Indian Ocean since the late Cretaceous, Geophys. J. Roy. Astron. Soc., 25, 437-528, 1971.

McKenzie, D. P., D. Davies, and P. Molnar, Plate tectonics of the Red Sea and East Africa, Nature, 226, 243-248, 1970.

Minster, J. B., and T. H. Jordan, Present-day plate motions, J. Geophys. Res., 83, 5331-5354, 1978.

Minster, J. B., T. H. Jordan, P. Molnar, and E. Haines, Numerical modelling of instantaneous plate tectonics, Geophys. J. Roy. Astron. Soc., 36, 541-576, 1974.

Montadert, L., O. de Charpel, D. Roberts, P. Geunnoc, and J. Sibuet, Northeast Atlantic passive continental margins: Rifting and subsidence processes, in Deep Drilling Results in the Atlantic Ocean: Continental Margins and Paleoenvironment, Maurice Ewing Ser., vol. 3, edited by M. Talwani, W. Hey, and W. B. F. Ryan, Pp. 154 186, AGU, Washington, D. C., 1979.

Moore, D. G., Plate edge deformation and crustal growth, Gulf of California structural province, Geol. Soc. Am. Bull., 84, 1883-1906, 1973.

Moore, D. G., and E. C. Buffingham, Transform faulting and growth of the Gulf of California since the Late Pliocene, Science, 161, 1238-1241, 1963.

Morton, W. H., and R. Black, Crustal attenuation in Afar, in Afar Depression of Ethiopia, edited by A. Pilger and A. Rösler, pp. 55-65, Schweizerbart, Stuttgart, Germany, 1975.

Nafe, J. E., J. F. Hennion, and G. Peter, Geophysical measurements in the Gulf of Aden, in Preprints of Abstracts of Papers to be Presented at Afternoon Sessions, International Oceanographic Congress, edited by M. Sears, pp. 42-43, American Association for the Advancement of Science, Washington, D. C., 1959.

Needham, H. D., P. Choukroune, J. L. Cheminee, X. Le Pichon, J. Francheteau, and $P$. Tapponnier, The accreting plate boundary: Ardoukoba Rift (Northeast Africa) and the oceanic rift valley, Earth Planet. Sci. Lett., 28, 439-453, 1976.

Normark, W. R., and J. R. Curray, Geology and structure of the tip of Baja California, Mexico, Geol. Soc. Am. Bull, 79, 1589-1600, 1968. 
Olausson, E., and I. U. Olsson, Varve stratigraphy in a core from the Gulf of Aden, Palaeogr. Palaeoclimatol. Palaeoecol., 6, 87-103, 1969.

Phillips, J. D., and D. A. Ross, Continuous seismic reflexion profiles in the Red Sea, Phil. Trans. Roy. Soc. London, Ser. A., 143-152, 1970.

Phillips, R. P., Seismic refraction studies in the Gulf of California, in Marine Geology of the Gulf of California, edited by Tj. Van Andel and G. G. Shor, Am. Assoc. Pet. Geol. Mem, 3, 90-121, 1964.

Quennell, A. M., The structural and geomorphic evolution of the Dead Sea Rift, Quart. J. Geol. Soc. London, 114, 1-24, 1958.

Roeser, H. A., A detailed magnetic survey of the southern Red Sea, Geol. Jahrb., 13, 131-153, 1975.

Schilling, J.-G., Afar mantle plume: Rare earth evidence, Nature Phys. Sci, 242, 2-5, 1973.

Sclater, J. G., R. N. Anderson, and M. L. Bell, Elevation of ridges and evolution of the central eastern Pacific, J. Geophys. Res., 76, 78887915, 1971.

Searle, R. C., and D. A. Ross, A geophysical study of the Red Sea axial trough between $20.5^{\circ}$ and $22^{\circ} \mathrm{N}$, Geophys. J. Roy. Astr. Soc., 43, 555-572, 1975

Shipboard Scientific Party, Site 231, in Initial Reports of the Deep-Sea Drilling Project, vol. 24, edited by R. L. Fisher, E. T. Bunce et al., pp. 17-126, U.S. Government Printing Office, Washington, D. C., 1974.

Shipboard Scientific Party, Drilling in the Gulf of California, Geotimes, 24, 18-20, 1979.

Simpson, E. S. W., J. G. Sclater, B. Parsons, I. Norton, and L. Meinke, Mesozoic magnetic lineation in the Mozambique Basin, Earth Planet. Sci. Lett., 43, 260-264, 1979.

Somaliland Oil Exploration Co. Ltd., A geological reconnaissance of the sedimentary deposits of the protectorate of British Somaliland, 42 pp., Crown Agents for the Colonies, London, 1954.
Stoneley, R., Evolution of the continental margins bounding a former southern Tethys, in The Geology of Continental Margins, edited by C. A. Burk and C. L. Drake, pp. 889-903, Springer, New York, 1974.

Sykes, L. R., Seismicity of the Indian Oćean and a possible nascent island arc between Ceylon and Australia, J. Geophys. Res, 75, 5041-5055, 1970.

Talwani, M., J. Mutter, R. Houtz, and M. König, The crustal structure and evolution of the area underlying the magnetic quiet zone on the margin south of Australia, in Geological and Geophysical Investigations of Continental Margins, edited by J. S. Watkins, $L$. Montadert, and P. W. Dickerson, pp. 151-175, American Association of Petroleum Geologists, Tulsa, Okla., 1978.

Tramontini, C., and D. Davies, A seismic refraction survey in the Red Sea, Geophys. J. Roy. Astron. Soc., 17, 225-241, 1969.

Watts, A. B., and M. S. Steckler, Subsidence and eustasy at the continental margin of eastern North America, in Deep Drilling Results in the Atlantic Ocean: Continental Margins and Paleoenvironment, Maurice Ewing Ser., vol. 3, edited by M. Talwani, W. Hey, and W. B. F. Ryan, pp. 218-239, AGU, Washington, D. C., 1979.

Weissel, J. K., C. A. Geller, R. N. Anderson, and B. R. Niani, Intraplate deformation in the Central Indian Ocean I: Seismic Reflection, piston core and gravity observations (abstract), Eos Trans. $A G U, 60,310,1979$.

Whitmarsh, R. B., The Owen Basin off the southeast margin of Arabia, Geophys. J. Roy. Astron. Soc., 58, 441-470, 1979.

(Received August 24, 1979; revised March 3, 1980; accepted April 28, 1980.) 